\title{
The Calcium-Signaling Toolkit in Cancer: Remodeling and Targeting
}

\author{
Sarah J. Roberts-Thomson, ${ }^{1}$ Silke B. Chalmers, ${ }^{1}$ and Gregory R. Monteith ${ }^{1,2}$ \\ ${ }^{1}$ The School of Pharmacy, The University of Queensland, Brisbane, Queensland 4072, Australia \\ ${ }^{2}$ Mater Research Institute, The University of Queensland, Translational Research Institute, Brisbane, Queensland \\ 4072, Australia \\ Correspondence: greg@pharmacy.uq.edu.au
}

Processes that are important in cancer progression, such as sustained cell growth, invasion to other organs, and resistance to cell death inducers, have a clear overlap with pathways regulated by $\mathrm{Ca}^{2+}$ signaling. It is therefore not surprising that proteins important in $\mathrm{Ca}^{2+}$ signaling, sometimes referred to as the " $\mathrm{Ca}^{2+}$ signaling toolkit," can contribute to cancer cell proliferation and invasiveness, and the ability of agents to induce cancer cell death. $\mathrm{Ca}^{2+}$ signaling is also critical in other aspects of cancer progression, including events in the tumor microenvironment and processes involved in the acquisition of resistance to anticancer therapies. This review will consider the role of $\mathrm{Ca}^{2+}$ signaling in tumor progression and highlight areas in which a better understanding of the interplay between the $\mathrm{Ca}^{2+}$-signaling toolkit and tumorigenesis is still required.

$T^{\text {he }}$ he calcium ion $\left(\mathrm{Ca}^{2+}\right)$ is a crucial regulator of a plethora of diverse cellular processes. These $\mathrm{Ca}^{2+}$ signal-sensitive processes control events as distinct as muscle contraction to gene transcription, and hormone release to neurotransmission (Carafoli 2002). As coined by Bootman et al. (2001), a "toolkit" of different $\mathrm{Ca}^{2+}$ channels, pumps, and exchangers regulate cellular $\mathrm{Ca}^{2+}$ levels in compartments (Fig. 1), enabling precise control of these different processes. Although beyond the scope of this review to provide a complete overview of $\mathrm{Ca}^{2+}$ signaling, readers are encouraged to consult comprehensive reviews (Bootman et al. 2001; Carafoli 2002; Monteith et al. 2017). Briefly, a variety of cell membrane hormone/growth factor receptors can induce increases in cytosolic $\mathrm{Ca}^{2+}\left(\left[\mathrm{Ca}^{2+}\right]_{\mathrm{CYT}}\right)$ by generating inositol $1,4,5$ trisphosphate $\left(\mathrm{IP}_{3}\right)$ and releasing $\mathrm{Ca}^{2+}$ from internal endoplasmic reticulum $\mathrm{Ca}^{2+}$ stores via the opening of $\mathrm{IP}_{3-}$ activated $\mathrm{Ca}^{2+}$ channels (Fig. 1A). Refilling these stores after depletion occurs by a specific $\mathrm{Ca}^{2+}$ influx pathway referred to as store-operated $\mathrm{Ca}^{2+}$ entry (SOCE). SOCE involves $\mathrm{Ca}^{2+}$ influx via ORAIl $\mathrm{Ca}^{2+}$ channels after activation by the endoplasmic reticulum $\mathrm{Ca}^{2+}$ store sensor stromal interaction molecule (STIM) 1 (Fig. 1A). Other $\mathrm{Ca}^{2+}$ influx pathways include those activated by changes in membrane potential (e.g., L-type and T-type voltage-gated $\mathrm{Ca}^{2+}$ channels) and external stimuli such as temperature (e.g., transient receptor potential [TRP] channels)

Editors: Geert Bultynck, Martin D. Bootman, Michael J. Berridge, and Grace E. Stutzmann

Additional Perspectives on Calcium Signaling available at www.cshperspectives.org

Copyright (C) 2019 Cold Spring Harbor Laboratory Press; all rights reserved; doi: 10.1101/cshperspect.a035204

Cite this article as Cold Spring Harb Perspect Biol 2019;11:a035204 
S.J. Roberts-Thomson et al.
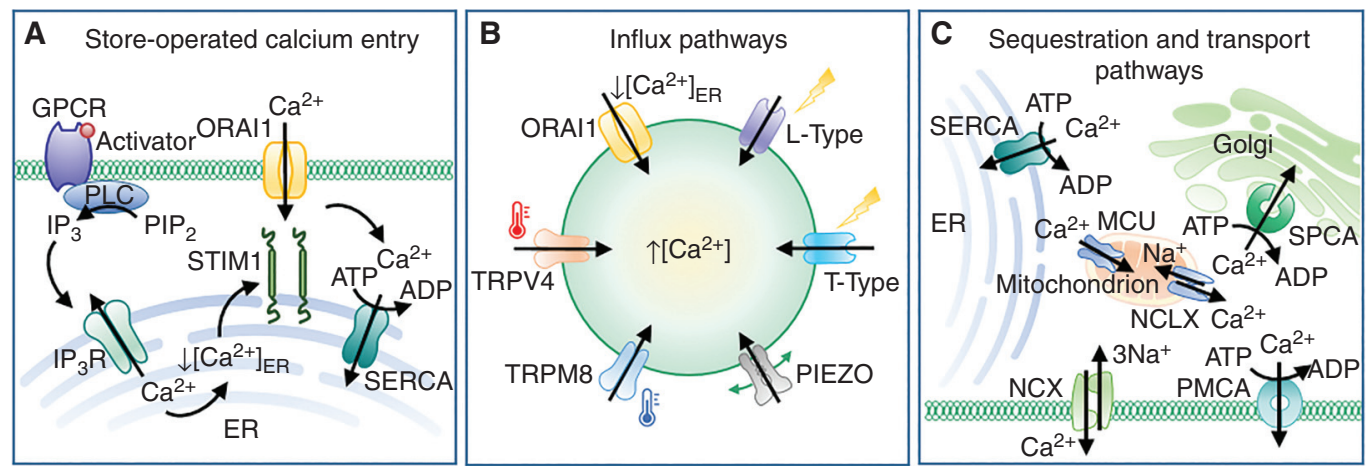

Figure 1. An overview of $\mathrm{Ca}^{2+}$ signaling pathways and toolkit members. (A) Activation of plasmalemmal receptors including G-protein-coupled receptors (GPCRs) can initiate the release of internal $\mathrm{Ca}^{2+}$ stores from the endoplasmic reticulum (ER) through the formation of secondary messenger $\mathrm{IP}_{3}$. The reduction in $\mathrm{ER} \mathrm{Ca}^{2+}$ levels is sensed by STIM1, which subsequently activates ORAI1 channels to permit $\mathrm{Ca}^{2+}$ influx and ER refilling via the ER $\mathrm{Ca}^{2+}$ pump sarco/endoplasmic $\mathrm{Ca}^{2+}$ ATPases (SERCA) (Trebak and Putney 2017). Collectively, this process constitutes store-operated $\mathrm{Ca}^{2+}$ entry (SOCE). (B) In addition to internally activated pathways, $\mathrm{Ca}^{2+}$ influx can be initiated by external stimuli acting on a plethora of $\mathrm{Ca}^{2+}$ toolkit members (Berridge et al. 2003). Examples include voltage-gated calcium channels, of which L-type and T-type channels are subtypes, stretch-activated PIEZO channels, and the transient receptor potential (TRP) superfamily of ion channels, sensitive to a range of stimuli, including warm (TRPV4) and cool (TRPM8) temperatures (Berridge et al. 2003; Pedersen et al. 2005; Martinac and Poole 2018). (C) Cytosolic $\mathrm{Ca}^{2+}$ levels are tightly controlled through the orchestrated work of pumps and exchangers. $\mathrm{Ca}^{2+}$ toolkit members SERCA and secretory pathway $\mathrm{Ca}^{2+}$ ATPases (SPCAs) sequester $\mathrm{Ca}^{2+}$ within internal stores of the ER and Golgi, respectively, whereas plasma membrane bound toolkit members plasma membrane $\mathrm{Ca}^{2+}$-ATPases (PMCAs) and $\mathrm{Na}^{+} / \mathrm{Ca}^{2+}$ exchanger expel $\mathrm{Ca}^{2+}$ through active or $\mathrm{Na}^{+}$gradient-dependent means. Mitochondrial $\mathrm{Ca}^{2+}$ influx and efflux occur via the mitochondrial calcium $\mathrm{Ca}^{2+}$ uniporter (MCU) and the mitochondrial $\mathrm{Na}^{+} / \mathrm{Ca}^{2+}$ exchanger (NCLX), respectively (Berridge et al. 2003; Rizzuto et al. 2012).

and stretch (e.g., PIEZO channels) (Fig. 1B; Berridge et al. 2003; Pedersen et al. 2005). Other members of the $\mathrm{Ca}^{2+}$ tool kit include $\mathrm{Ca}^{2+}$ pumps that actively expel $\mathrm{Ca}^{2+}$ across the plasma membrane (plasma membrane $\mathrm{Ca}^{2+}$-ATPases [PMCAs] and $\mathrm{Na}^{+} / \mathrm{Ca}^{2+}$ exchangers [NCX]) (Fig. 1C). The toolkit also includes members that sequester $\mathrm{Ca}^{2+}$ into the endoplasmic reticulum (sarco/endoplasmic $\mathrm{Ca}^{2+}$ ATPases [SERCAs]) or the Golgi (secretory pathway $\mathrm{Ca}^{2+}$ ATPases [SPCAs]), or can regulate $\mathrm{Ca}^{2+}$ levels in intracellular organelles such as those recently identified in the mitochondria (Fig. 1C).

Distinct cellular outcomes as a result of $\mathrm{Ca}^{2+}$ signaling are achieved by differential regulation of the magnitude of $\left[\mathrm{Ca}^{2+}\right]_{\mathrm{CYT}}$ increases, as well as the frequency or localization of $\mathrm{Ca}^{2+}$ increases (Berridge 1997; Kar and Parekh 2015). As will be evident throughout this review, there are cases in which the expression of members of this toolkit are altered in cancer, and, in some cases, this altered expression is manifested predominantly in a specific cancer subtype.

Studies in both cancer and noncancer cells have linked $\mathrm{Ca}^{2+}$ signaling with key events relevant to tumor progression such as proliferation, migration, and apoptosis. Although cardiovascular and neurological diseases were the initial focus of $\mathrm{Ca}^{2+}$ signaling in disease, the connections between $\mathrm{Ca}^{2+}$ signaling and processes important in the hallmarks of cancer (Hanahan and Weinberg 2000, 2011) have resulted in $\mathrm{Ca}^{2+}$ signaling being studied in cancer. Although studies initially examined in vitro cancer cell processes, development of the field has identified roles for $\mathrm{Ca}^{2+}$ toolkit members in the growth and metastasis of cancer cells in vivo. Even the acquisition of resistance to some cancer therapies is linked to specific $\mathrm{Ca}^{2+}$-permeable ion channels. As cancer research turns toward the 
The Calcium-Signaling Toolkit in Cancer

tumor microenvironment as an important mediator in cancer progression, recent studies in $\mathrm{Ca}^{2+}$ signaling have begun to define a role for $\mathrm{Ca}^{2+}$ in the tumor microenvironment (Weaver et al. 1996; Kenny et al. 2007; Bissell and Hines 2011; Boudreau et al. 2012; Mao et al. 2013). Collectively, this work has led to many researchers proposing that components of the $\mathrm{Ca}^{2+}$ signaling toolkit may represent new therapeutic targets in cancer therapy (Monteith et al. 2007; Dubois et al. 2013). Although it is not possible to provide a comprehensive evaluation of the entire field in this short review, we have aimed to provide an overview of what we consider to be some of the key areas and issues. The topics we discuss include examples and mechanisms of changes in the expression of $\mathrm{Ca}^{2+}$ signal regulators in some cancers, and the importance of the $\mathrm{Ca}^{2+}$ signal in cells of the primary tumor and the tumor microenvironment. We also seek to provide a snapshot of issues related to the targeting of members of the $\mathrm{Ca}^{2+}$ signaling toolkit in cancer therapy.

\section{REMODELING OF THE CALCIUM- SIGNALING TOOLKIT IN CANCER CELLS}

Studies have identified particular $\mathrm{Ca}^{2+}$-permeable ion channels or $\mathrm{Ca}^{2+}$ pumps that are expressed at higher levels in cancers compared with normal surrounding tissue. TRPM8, a $\mathrm{Ca}^{2+}$-permeable ion channel, which is now mostly studied for its role in the detection of lower temperatures in sensory neurons, was actually first reported in a study identifying proteins overexpressed in prostate cancers (Tsavaler et al. 2001). Elevated TRPM8 expression occurs in many malignancies, including those of the breast, lung, and colon (Tsavaler et al. 2001), although TRPM8 appears to be lost in some cancer cell lines (Yapa et al. 2018). The remodeling of expression of specific members of the $\mathrm{Ca}^{2+}$ signaling toolkit in cancer has been extensively reviewed (Monteith et al. 2007, 2012; Lee et al. 2011; Lastraioli et al. 2015; Shapovalov et al. 2016). Similarly to TRPM8, there are $\mathrm{Ca}^{2+}$ channels and pumps that are overexpressed in more than one malignancy, such as TRPV6, which is overexpressed in several cancers including prostate and breast (Zhuang et al. 2002; Fixemer et al.
2003; Bolanz et al. 2008). Indeed, a TRPV6 inhibitor, SOR-C13, underwent a phase I clinical trial in patients with advanced solid cancers, including colorectal, prostate, and breast (Fu et al. 2017), and has U.S. Food and Drug Administration approval as an orphan drug for pancreatic and ovarian cancers. In other cases, alterations may be more predominant in a particular cancer as exemplified by the $\mathrm{Ca}^{2+}$-permeable ion channel TRPC6, in which overexpression occurs in breast and prostate cancers, but with lower expression in colorectal cancers (Guilbert et al. 2008; Yue et al. 2009; Sozucan et al. 2015). Examples also exist in which the overexpression of a particular $\mathrm{Ca}^{2+}$ channel or pump is specific to a cancer subtype. The expression of the aforementioned highly $\mathrm{Ca}^{2+}$-permeable TRPV6 is correlated with estrogen receptor levels in breast cancer. Patients with estrogen receptor-positive breast cancers can be treated with hormone therapies, including estrogen receptor blockers or aromatase inhibitors. Estrogen receptor-negative breast cancers are intrinsically resistant to these hormone therapies, limiting the therapeutic options available for these patients. Considering this, the correlation of increased TRPV6 expression in estrogen receptor-negative breast cancers, associated with an increase in TRPV6 gene copy number, is a significant finding (Peters et al. 2012). Although TRPV6 expression is associated with breast cancer hormone receptor expression, some members of the $\mathrm{Ca}^{2+}$ signaling toolkit are linked to specific molecular subtypes, where cancers are classified by their expression of groups of genes. For TRPV4, expression is elevated in breast cancers of the basal molecular subtype compared with subtypes known as luminal A, luminal B, and HER2 breast cancers (Peters et al. 2017). In the case of MDA-MB468 basal breast cancer cells, the degree of TRPV4 overexpression is sufficient for the cell line to be highly sensitive to cell death initiated by the TRPV4 activator GSK1016790A (Peters et al. 2017).

Functional consequences can arise from remodeling of the $\mathrm{Ca}^{2+}$ signaling toolkit in cancer, potentially impacting on the nature of $\mathrm{Ca}^{2+}$ signaling in cancers. This is evident with the $\mathrm{Ca}^{2+}$ channel ORAI3. In contrast to the canonical 


\section{S.J. Roberts-Thomson et al.}

SOCE channel, ORAI1, few studies have identified endogenous roles for ORAI3 in SOCE. In estrogen receptor-positive breast cancer cells, but not in estrogen receptor-negative breast cancer cells; however, ORAI3 expression levels are increased (Motiani et al. 2010). Assessment of clinical samples shows higher levels of ORAI3 in luminal breast cancer subtypes compared with the basal molecular subtype, which overlap with estrogen receptor-positive and estrogen receptor-negative breast cancer subtypes, respectively (Azimi et al. 2019). Unlike in most other cell types, and in contrast to the estrogen receptor-negative breast cancer cell lines tested, the overexpression of ORAI3 in estrogen receptorpositive breast cancer cells is associated with ORAI3 also contributing along with ORAI1 to SOCE (Motiani et al. 2010). This suggests that the remodeling of the $\mathrm{Ca}^{2+}$ signaling toolkit in cancer can involve a switch, not just in toolkit component expression, but also the nature of their contribution to $\mathrm{Ca}^{2+}$ transport or homeostasis. Another example of this switch is evident in prostate cancer cells. Prostate cancer cells also have elevated expressions of ORAI3 (Dubois et al. 2014), and in this context high levels of ORAI3 protein appear to promote formation of a heterometric ORAI1/3 channel, which is more responsive to pro-proliferative signals such as arachidonic acid and a cellular phenotype with less SOCE (Dubois et al. 2014). This reduction in SOCE bestows a reduced sensitivity to some apoptotic stimuli that normally induce cell death through increases in $\mathrm{Ca}^{2+}$ influx (Dubois et al. 2014). Another aspect of remodeling of $\mathrm{Ca}^{2+}$ signaling in cancer could involve changes in the relationship between key players in $\mathrm{Ca}^{2+}$ homeostasis and $\mathrm{Ca}^{2+}$-dependent processes, such as the interface between mitochondria and the endoplasmic reticulum, as has been recently reviewed (Kerkhofs et al. 2017).

Changes in $\mathrm{Ca}^{2+}$ signaling can also be consequential to gene mutations. Genetic mutations are a cancer hallmark and occur in proto-oncogenes or tumor suppressor genes acting as drivers for cellular transformation. Indeed, as reviewed elsewhere, there are important links between many oncogenes, tumor suppressors, and $\mathrm{Ca}^{2+}$ signaling (Marchi et al. 2014; Bittre- mieux et al. 2016). The RAS family of genes are proto-oncogenes that are frequently mutated in human cancers (Prior et al. 2012). RAS proteins are GTPases with a crucial role in proliferation pathways (Prior et al. 2012). Mutations in the KRAS isoform (specifically G13D) drive changes in members of the $\mathrm{Ca}^{2+}$ signaling toolkit, with effects on $\mathrm{Ca}^{2+}$ release from the endoplasmic reticulum and on SOCE. K-RAS mutations alter the suite of endoplasmic reticulum $\mathrm{Ca}^{2+}$ regulators expressed in colorectal cancer cells, including the expression of $\mathrm{Ca}^{2+}$ release channel inositol 1,4,5-trisphosphate receptor $\left(\mathrm{IP}_{3} \mathrm{R}\right)$ isoforms. Accompanying these expression changes is a suppression of $\mathrm{IP}_{3}$-dependent $\mathrm{Ca}^{2+}$ release (Pierro et al. 2014). A colorectal cancer cell line where the oncogenic K-RAS G13D mutation was deleted had increased $\mathrm{IP}_{3}$-mediated $\mathrm{Ca}^{2+}$ release. Moreover, silencing of K-RAS phenocopied this effect in the isogenic colorectal cancer cell line with the K-RAS G13D mutation (HCT116) (Pierro et al. 2014). Many growth factors drive proliferation through $\mathrm{IP}_{3}$-dependent $\mathrm{Ca}^{2+}$ release; hence, suppression of $\mathrm{IP}_{3}$-mediated $\mathrm{Ca}^{2+}$ release in K-RAS-mutated cancer may seem counterintuitive. However, mutated K-RAS remodeling of $\mathrm{IP}_{3}$-dependent $\mathrm{Ca}^{2+}$ release bestows reduced sensitivity to apoptotic stimuli via alteration of mitochondrial $\mathrm{Ca}^{2+} \mathrm{lev}$ els (Pierro et al. 2014). K-RAS mutations in colorectal cancer also alter SOCE and the relative expression of the SOCE regulators STIM1 and STIM2 (Pierro et al. 2018). The ability of the phosphorylation state of K-RAS to regulate Bcl-xl-mediated regulation of $\mathrm{IP}_{3}$ receptors adds another dimension to the intersection between K-RAS, cell survival, and $\mathrm{Ca}^{2+}$ signaling (Sung et al. 2013). PTEN is another gene that is frequently mutated in cancer (Milella et al. 2015). Loss of PTEN function drives changes in $\mathrm{Ca}^{2+}$ signaling via $\mathrm{IP}_{3} \mathrm{Rs}$ by increasing FBXL2-dependent degradation of $\mathrm{IP}_{3} \mathrm{R} 3(\mathrm{Ku}-$ chay et al. 2017). The tumor suppressor BRCA1-associated protein 1 (BAP1) is also a regulator of $\mathrm{IP}_{3} \mathrm{R} 3$ stability and its loss reduces $\mathrm{IP}_{3} \mathrm{R} 3$ levels and $\mathrm{Ca}^{2+}$ release, which may be important in bestowing apoptosis insensitivity to a variety of genomic stress inducers (Bononi et al. 2017). Although the above examples illus- 
trate that genes commonly mutated in cancer can affect $\mathrm{Ca}^{2+}$ signaling, there are clear future opportunities to define and assess gene mutations in members of the $\mathrm{Ca}^{2+}$ signaling toolkit and their consequences. Indeed, the recent identification of rare ORAIl mutations in some cancers, and the association of some of these mutations with enhanced ORAI1 constitutive channel activity (Frischauf et al. 2017), highlights potential significance and the need for further studies.

With disease progression, there can also be a remodeling of $\mathrm{Ca}^{2+}$ channels, pumps, or signaling. Epithelial-mesenchymal transition (EMT) is a cancer progression mechanism whereby epithelial cancer cells adopt a phenotype that has less epithelial markers but is rich in mesenchymal markers, and become less proliferative with an up-regulation of pathways associated with metastasis and therapeutic resistance (Ye and Weinberg 2015; Zhang and Weinberg 2018). EMT modulators have been proposed as potential therapeutic agents (Davis et al. 2014b). In both hypoxia and epidermal growth-factor-induced EMTs in MDA-MB-468 breast cancer cells, there is reduced sensitivity to the $\left[\mathrm{Ca}^{2+}\right]_{\mathrm{CYT}}$-increasing effects of ATP (Davis et al. 2011; Azimi et al. 2016). Indeed, changes in $\mathrm{Ca}^{2+}$ signaling and/or expression of members of the $\mathrm{Ca}^{2+}$ signaling toolkit occur as a consequence of EMT (Davis et al. 2011, 2012, 2013; Mahdi et al. 2015; Qi et al. 2016; Wu et al. 2017; Gershkovitz et al. 2018b). Hence, a variety of factors may contribute to altered $\mathrm{Ca}^{2+}$ signaling and/or expression of specific $\mathrm{Ca}^{2+}$ channels and pumps in cancer cells, including increased gene copy number, altered transcription pathways, and microenvironmental factors such as growth factors and hypoxia.

\section{CANCER CELLS AND THE CALCIUM SIGNAL}

The intersection between events within the cancer cell that are important in tumor progression and $\mathrm{Ca}^{2+}$ signaling have been extensively reviewed (Roderick and Cook 2008; Prevarskaya et al. 2011; Azimi et al. 2014; Stewart et al. 2015; Monteith et al. 2017). Examples include the roles of specific $\mathrm{Ca}^{2+}$ signals during cell cycle progression (Roderick and Cook 2008), the importance of $\mathrm{Ca}^{2+}$ signals during cancer cell migration and release of matrix metalloproteinase (MMP) during cancer cell invasion (Prevarskaya et al. 2011), and the roles of $\mathrm{Ca}^{2+}$ signals in cell death pathways (Danese et al. 2017; Ivanova et al. 2017). The expansive involvement of $\mathrm{Ca}^{2+}$ toolkit members in the progression of a single type of malignancy, breast cancer, is summarized in Figure 2. Given the scope of these phenomena and their discussions in other recent reviews, here we will highlight some selected specific examples that clearly show the significance of $\mathrm{Ca}^{2+}$ signals in cancer cell processes important in tumor progression. Studies using in vivo models, in particular those involving silencing of a specific $\mathrm{Ca}^{2+}$ channel or pump have been prioritized for discussion, and where possible, more recent examples from different cancer types and members of the $\mathrm{Ca}^{2+}$ toolkit are presented.

\section{Proliferation}

$\mathrm{Ca}^{2+}$ signaling has an important role in the proliferation of different cancer cell lines. In cervical cancer, STIM1 expression is elevated compared with adjacent nonneoplastic epithelia, is positively correlated with tumor size, and is higher in patients with lymph node metastasis (Chen et al. 2011). STIM1 silencing significantly reduces cell cycle progression of the cervical cancer cell line $\mathrm{SiH}$ a with arrest in the $\mathrm{S}$ and $\mathrm{G}_{2} / \mathrm{M}$ phases and an increase in p21 protein levels (Chen et al. 2011). STIM1 silencing also reduces tumor weight in cervical cancer in vivo models. Conversely, the ability of STIM1 overexpression to increase tumor weight places STIM1 as a driver of cervical cancer cell growth in vivo (Chen et al. 2011). However, this effect may not be solely caused by the aforementioned cell cycle effects, because STIM1 promotes the secretion of the proangiogenic factor VEGF-A and stimulates cervical cancer angiogenesis (Chen et al. 2011). Using a small cohort of glioma brain cancer samples, TRPC6 expression was shown to be elevated at the protein and messenger RNA (mRNA) levels compared with normal control brain tissue controls, with 
S.J. Roberts-Thomson et al.

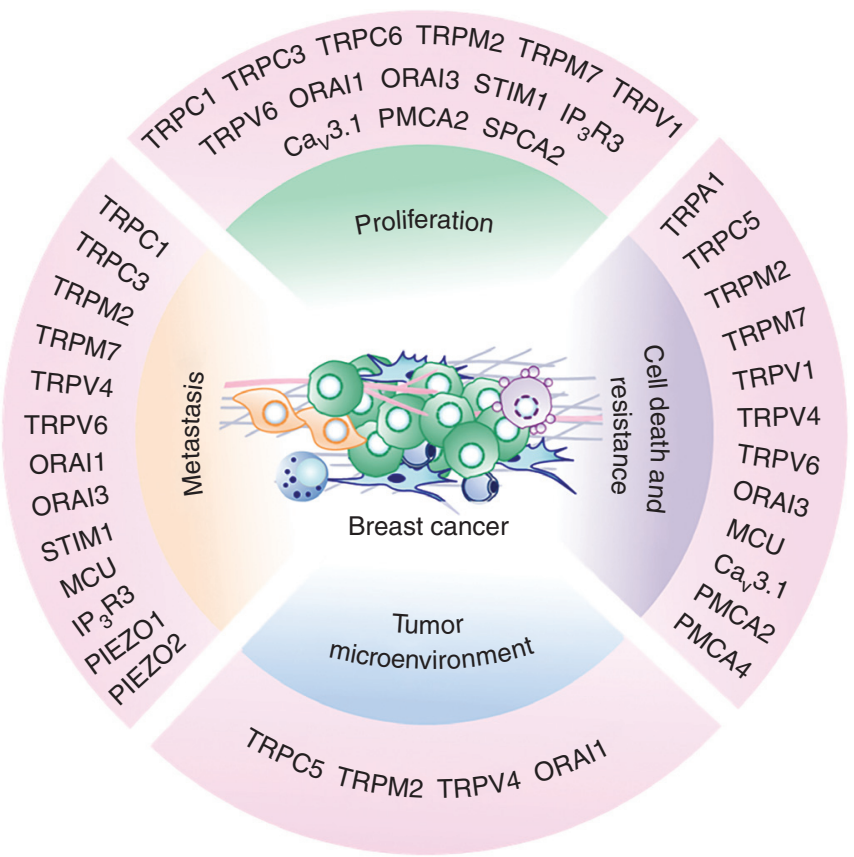

Figure 2. Examples of the diversity and multitude of $\mathrm{Ca}^{2+}$ toolkit members implicated in four aspects of breast cancer progression: proliferation, metastasis, cell death and resistance, and the tumor microenvironment. Note that not all targets have been assessed in vivo or using pharmacological agents. TRPA1 (Takahashi et al. 2018), TRPC1 (El Hiani et al. 2009; Faouzi et al. 2016; Schaar et al. 2016), TRPC3 (Zhang et al. 2012), TRPC5 (Ma et al. 2012, 2014; Zhu et al. 2015), TRPC6 (Aydar et al. 2009), TRPM2 (Hopkins et al. 2015; Koh et al. 2015; Gershkovitz et al. 2018a,b,c), TRPM7 (Guilbert et al. 2009; Kim 2012; Davis et al. 2014a), TRPV1 (Weber et al. 2016), TRPV4 (Fiorio Pla et al. 2012; Lee et al. 2016; Peters et al. 2017), TRPV6 (Bolanz et al. 2008; Peters et al. 2012), ORAI1 (Yang et al. 2009; Feng et al. 2010; Badaoui et al. 2018; Liu et al. 2018b), ORAI3 (Faouzi et al. 2013; Motiani et al. 2013; Hasna et al. 2018), STIM1 (Yang et al. 2009, 2018), MCU (Curry et al. 2013; Tosatto et al. 2016), IP ${ }_{3}$ R3 (Szatkowski et al. 2010; Mound et al. 2017), Ca 3.1 (Ohkubo and Yamazaki 2012), PMCA2 (VanHouten et al. 2010; Curry et al. 2016; Peters et al. 2016), PMCA4 (Curry et al. 2012), PIEZO1 (Li et al. 2015), and PIEZO2 (Pardo-Pastor et al. 2018).

TRPC6 protein expression greater in higher grade gliomas (Ding et al. 2010). TRPC6 shRNA-mediated silencing in glioma cell lines attenuates platelet-derived growth factor-mediated increases in $\left[\mathrm{Ca}^{2+}\right]_{\mathrm{CYT}}$, inhibits colony formation in vitro, and produces cell cycle arrest at the $G_{2} / M$ phase of the cell cycle (Ding et al. 2010). An association between TRPC6 and glioma growth also occurs in both subcutaneous and intracranial xenograft models where suppression of TRPC6 expression, using a dominant-negative construct, attenuated growth in vitro (Ding et al. 2010).

In prostate cancer, mRNA levels of the human analogue of a voltage-gated $\mathrm{Ca}^{2+}$ channel subunit gene (Tedeschi et al. 2016), CAC$N A 2 D 2$, are elevated and its silencing reduces the proliferation and percentage of LNCaP cells in the $\mathrm{G}_{2} / \mathrm{M}$ and $\mathrm{S}$ phases (Warnier et al. 2015). Moreover, exogenous overexpression of $C A C$ $N A 2 D 2$ significantly increases the size of LNCaP tumors in vivo (Warnier et al. 2015). Of significance in $\mathrm{Ca}^{2+}$ signaling research, and particularly important in the context of cancer, silencing or inhibiting a $\mathrm{Ca}^{2+}$-permeable ion channel expressed in a cancer cell line does not necessarily produce antiproliferative effects (Monteith et al. 2007); our own, and other groups, have observed many cases in which the silencing of a specific $\mathrm{Ca}^{2+}$ channel has no effect on cancer cell prolif- 
eration. There are even cases in which a $\mathrm{Ca}^{2+}$ permeable ion channel component may actually have a tumor-suppressive role. Indeed, the voltage-gated $\mathrm{Ca}^{2+}$ channel subunit encoded by the CACNA2D3 gene is such an example. Overexpression of CACNA2D3 reduces the proliferation of glioma cell lines in vitro and in vivo (Jin et al. 2017), the channel has reduced expression in clinical samples of gliomas compared with normal controls, and low expression of this channel is correlated with poorer patient prognosis than high expression (Jin et al. 2017). Diverse tumor-suppressing/-promoting roles of specific $\mathrm{Ca}^{2+}$ channels maybe because of subtle differences in the remodeling of the $\mathrm{Ca}^{2+}$ signal. In this context, in gastric cancer, higher $C A C$ $N A 1 G$ expression is associated with better overall survival, but the expression of two other T-type $\mathrm{Ca}^{2+}$ channels (CACNA1H and CAC$N A 1 I$ ) is associated with poorer prognosis (Fornaro et al. 2017).

\section{Metastasis}

Although inherently more difficult to study in vivo compared with tumor growth, numerous studies have defined roles for $\mathrm{Ca}^{2+}$ signaling toolkit members in metastatic progression; the ultimate cause of mortality in most cancers. Many studies have linked the molecular components of SOCE with processes important in cancer cell metastasis, such as migration and invasion (Chen et al. 2011; Hammadi et al. 2012; Yang et al. 2013; Kim et al. 2014; Umemura et al. 2014; Xia et al. 2016; Diez-Bello et al. 2017; Gueguinou et al. 2017). ORAI1 and STIM1 were first linked with metastasis in breast cancer in which ORAI1 and STIM1 silencing in MDAMB-231 breast cancer cells reduced invasiveness in vitro and metastasis in vivo (Yang et al. 2009). Mechanistically, in vitro studies implicate a change in focal adhesion protein turnover as a consequence of suppression of SOCE by ORAI1 and STIM1 silencing, resulting in the suppression of the motility and invasiveness capacity of cancer cells (Yang et al. 2009). L-type voltagegated $\mathrm{Ca}^{2+}$ channels were recently associated with collective migration of squamous cell carcinoma cells (Grasset et al. 2018). At high con- centrations, diltiazem and verapamil, clinically used L-type $\mathrm{Ca}^{2+}$ channel blockers, significantly reduce the invasive properties of patient-derived spheroid cultures, as well as invasion of squamous cell carcinoma patient-derived xenografts in an in vivo mouse model (Grasset et al. 2018). Although gene silencing experiments are still required to confirm that the L-type voltage-gated channel responsible for these effects is the proposed $\mathrm{Ca}_{\mathrm{V}} 1.1$ subtype, this study is an exemplar for the use of more diverse in vivo models to supplement the commonly used cell line xenograft and tail injection metastasis models.

The importance of $\mathrm{Ca}^{2+}$ signaling in metastasis is not confined to mediators of $\mathrm{Ca}^{2+}$ influx. Despite the relatively recent molecular identification of the mitochondrial $\mathrm{Ca}^{2+}$ uniporter (MCU), studies have already identified its important role in breast cancer and hepatocellular carcinoma metastasis. The MCU, which is a gateway for $\mathrm{Ca}^{2+}$ uptake into the mitochondria, is an obvious controller of cellular metabolism, and in breast cancer cells it is a regulator of mitochondrial relative oxygen species and hypoxiainducible factor $1 \alpha$ (Tosatto et al. 2016). These effects and others may explain the ability of MCU silencing to reduce the migration of MDA-MB-231 breast cancer cells in vitro as well as their metastatic progression in vivo as assessed by lymph node and lung metastasis size (Tosatto et al. 2016). In addition to highMCU expression being associated with poor survival in hepatocellular carcinoma patients, silencing of MCU reduces the migration and invasiveness of SMMC7721 hepatocellular carcinoma cells in vitro and lung metastasis formation in vivo (Ren et al. 2017). Data from the same study assessing the consequences of MCU overexpression, suggest that elevated MCU expression in some hepatocellular carcinomas promotes migratory and invasive pathways via elevated ROS production, subsequent promotion of JNK phosphorylation, and activation of MMP-2, focal adhesion turnover and lamellipodia formation (Ren et al. 2017). Melanoma cells with a mutation in the proto-oncogene BRAF appear to have a specific association with the plasma membrane $\mathrm{Ca}^{2+}$ pump alternative splice variant PMCA4b. The expression of PMCA4b is 
induced in BRAF-mutated melanoma cell lines after treatment with the clinically used mutant BRAF inhibitor vemurafenib (Hegedũs et al. 2017). Induced overexpression of PMCA4b in BRAF-mutated A375 melanoma cells significantly reduces their migration in vitro and the formation of lung metastasis in a tail-vein injection model (Hegedũs et al. 2017). As well as links to cancer cell migration and invasion, $\mathrm{Ca}^{2+}$ signaling is an important regulator of the ability of some cancer cells to transition to a more invasive phenotype through EMT (Davis et al. 2014a). Targeting specific $\mathrm{Ca}^{2+}$-permeable ion channels or modifying cellular $\mathrm{Ca}^{2+}$ signals are approaches that can be used to regulate EMT in various cancer cell lines (Davis et al. 2014a; Liu et al. 2014; Zhang et al. 2017; Zhu et al. 2017).

\section{Cancer Cell Death}

Given the intrinsic link between increases in $\left[\mathrm{Ca}^{2+}\right]_{\mathrm{CYT}}$ and/or mitochondrial $\mathrm{Ca}^{2+}$ levels and cell death (Rizzuto et al. 2003; Giacomello et al. 2007; Zhivotovsky and Orrenius 2011; Dubois et al. 2013; La Rovere et al. 2016; Bultynck and Parys 2018; Parys and Bultynck 2018), it is not surprising that members of the $\mathrm{Ca}^{2+}$ signaling toolkit have been investigated as potential ways to promote the death of cancer cells. The most direct evidence for the ability of the $\mathrm{Ca}^{2+}$ signal to induce cancer cell death and its potential clinical application is seen with $\mathrm{Ca}^{2+}$ electroporation. This method involves the application of high-voltage pulses after injection of a $\mathrm{Ca}^{2+}$ solution to a tumor region, which produces an overload of intracellular $\mathrm{Ca}^{2+}$ and cancer cell death (Frandsen et al. 2012). The process is effective in clinical trials (Falk et al. 2018) and offers potentially less damage to normal surrounding tissue than coadministration with agents such as bleomycin, because many cancer types are more sensitive to $\mathrm{Ca}^{2+}$ electroporation, perhaps because of compromised $\mathrm{Ca}^{2+}$ efflux pathways (Frandsen et al. 2017). An analogous phenomenon is seen with pharmacological $\mathrm{Ca}^{2+}$ channel activators producing death in cancer cells that overexpress their $\mathrm{Ca}^{2+}$ channel target (Zhang and Barritt 2004; Akbulut et al. 2015; Peters et al. 2017). The selective TRPV4 activator
GSK1016790A induces cell death in MDA-MB468 breast cancer cells overexpressing this $\mathrm{Ca}^{2+}$. permeable ion channel. This death is via two mechanisms, oncosis and apoptosis (Peters et al. 2017), with oncosis associated with close to maximal activation of TRPV4-mediated ion influx, and apoptosis associated with lower concentrations of GSK1016790A (Peters et al. 2017). The association between excessive $\left[\mathrm{Ca}^{2+}\right]_{\mathrm{CYT}}$ accumulation and cell death is also seen following PMCA1 silencing in MDA-MB-231 breast cancer cells, where compromised $\mathrm{Ca}^{2+}$ efflux results in greater sustained levels of global $\left[\mathrm{Ca}^{2+}\right]_{\mathrm{CYT}}$ and increased sensitivity to necrosis induced by the $\mathrm{Ca}^{2+}$ ionophore ionomycin (Curry et al. 2012).

Although the aforementioned studies provide clear examples of the ability of excessive global $\left[\mathrm{Ca}^{2+}\right]_{\mathrm{CYT}}$ to induce cancer cell death and how this might be exploited, there are examples of more nuanced contributions of members of the $\mathrm{Ca}^{2+}$ signaling toolkit to cancer cell death. One example is seen in the diverse effects of PMCA isoforms ( $\mathrm{Ca}^{2+}$ efflux pumps) in breast cancer cell death. MDA-MB-231 breast cancer cells express PMCA1, PMCA2, and PMCA4, but only PMCA1 has an appreciable ability to regulate acute changes in global $\left[\mathrm{Ca}^{2+}\right]_{\mathrm{CYT}}$ (Curry et al. 2012, 2016). However, silencing of PMCA4 or PMCA2 promotes the sensitivity of this breast cancer cell line to the proapoptotic effects of the Bcl-2 inhibitor navitoclax (Curry et al. 2012, 2016). Under some circumstances, cancer cells may be uniquely sensitive to targeting specific aspects of the $\mathrm{Ca}^{2+}$ signaling toolkit, as evidenced by the ability of disruption of endoplasmic reticulum to mitochondrial $\mathrm{Ca}^{2+}$ transfer to induce death in cancer cell lines, rather than autophagy as seen in nonmalignant cells (Cárdenas et al. 2010, 2016). Silencing of $\mathrm{IP}_{3} \mathrm{R} 1$ and $\mathrm{IP}_{3} \mathrm{R} 3$ or MCU disrupts endoplasmic reticulum to mitochondrial $\mathrm{Ca}^{2+}$ transfer and induces cell death in transformed but not normal human fibroblasts (Cárdenas et al. 2016). Indeed, pharmacological inhibition and silencing of $\mathrm{IP}_{3} \mathrm{Rs}$ promotes autophagic cell death in MCF-7 breast cancer cells (Singh et al. 2017). There are also examples in which current agents used to treat cancer or those undergoing clinical 
trials act, at least in part, through $\mathrm{Ca}^{2+}$ signaling to induce cancer cell death. This has been extensively reviewed elsewhere (Bonora et al. 2015; Bong and Monteith 2018; Kerkhofs et al. 2018). One specific example of how $\mathrm{Ca}^{2+}$ signaling and therapy intersect is seen in studies assessing the tumor suppressor p53 (Giorgi et al. 2015). Levels of $\mathrm{Ca}^{2+}$ in the endoplasmic reticulum are higher in cells with p53, as p53 is an activator of the pump that transports $\mathrm{Ca}^{2+}$ into this store (SERCA). Loss of p53 therefore reduces the amount of $\mathrm{Ca}^{2+}$ that is available to be transferred from the endoplasmic reticulum to the mitochondria, which is a requirement for apoptosis induced by some chemotherapeutic agents (Giorgi et al. 2015).

\section{THE TUMOR MICROENVIRONMENT AND THE CALCIUM SIGNAL}

Although the initial studies of $\mathrm{Ca}^{2+}$ signaling in cancer focused quite reasonably on the cancer cells themselves, cancer research has shifted focus toward the contribution of the tumor microenvironment to tumor progression. Depending on the cell type or context, cells in the tumor microenvironment can be contributors to tumor progression or they may help contain or suppress tumor growth.

The tumor microenvironment often includes infiltrating immune cells that can assist the removal of tumor cells, or alternatively, contribute to tumor progression via the release of agents such as growth factors and cytokines (Hanahan and Weinberg 2011). Although the role of $\mathrm{Ca}^{2+}$ signaling in immune-cancer cell interactions is still an understudied area, there is clear evidence for the role of SOCE in antitumor immunity in mice. Stim 1 and Stim 2 knockdown produces a phenotype of reduced activity of $\mathrm{CD}^{+} \mathrm{T}$ cells (cytotoxic lymphocytes), which are critical for suppressing the establishment and eventual growth of melanoma and colon cell carcinomas in mouse syngeneic allograft models (Weidinger et al. 2013). Although this suggests that agents that inhibit SOCE may always be detrimental in the context of tumor cell immunity, recent work suggests the area is complex, and that there may be an optimal level of
SOCE suppression whereby the activity of cytotoxic T lymphocyte and natural killer cells is actually increased with partial suppression of Orail (Zhou et al. 2018). Although studies with the SOCE pharmacological inhibitor BTP2 (Weidinger et al. 2013) did not show any such immune cell activation, studies with other SOCE inhibitors (such as Synta66 [Azimi et al. 2017, 2018]) now seem warranted to fully define this phenomena. The role of SOCE, and other forms of $\mathrm{Ca}^{2+}$ influx, in immune cell-mediated tumorpromoting inflammatory signaling and other pathways also requires attention. This is elegantly exemplified by the recent study of T-cell acute lymphoblastic leukemia (T-ALL). Mice lacking SOCE have reduced cancer-induced inflammation in organs with leukemia invasion in a NOTCH1-dependent model of T-ALL. Consequentially, there is reduced necroinflammatory responses in leukemia-infiltrated organs and improved survival in mice with leukemic cells that lack SOCE (Saint Fleur-Lominy et al. 2018).

One of the most important requirements of the tumor microenvironment is the establishment and maintenance of a tumor vasculature to supply oxygen and nutrients for tumor growth. Disruption of the tumor vasculature is the mechanism underlying clinically used angiogenesis inhibitors. $\mathrm{A} \mathrm{Ca}^{2+}$-permeable ion channel linked to angiogenesis and the tumor vasculature is TRPV4. Although, whether inhibition or activation of TRPV4 is the best strategy for reducing angiogenesis, or whether either may be appropriate, is a matter of debate. TRPV4 expression is elevated in endothelial cells derived from breast cancers (Fiorio Pla et al. 2012). Pharmacological inhibition and knockdown of TRPV4 reduces arachidonic acid-induced promotion of migration in endothelial cells from breast cancers, implicating an important role for TRPV4 in mediating the effects of some proangiogenic stimuli (Fiorio Pla et al. 2012). Hence, inhibition of TRPV4 could be analogous to antiangiogenesis drugs used in cancer therapy. Conversely, direct pharmacological activation of TRPV4 partly restores normal vasculature in tumors in vivo, and through this mechanism, TRPV4 activation may help improve therapy effectiveness by improving the de- 
livery of cytotoxic therapy to the tumor mass as has been shown in vivo (Adapala et al. 2016). Clearly there will be other $\mathrm{Ca}^{2+}$ channels that play critical roles in angiogenesis. Indeed, ORAI1 is linked to the ability of hypoxia to promote colon cancer cells to activate angiogenesis. Silencing of ORAI1 in HCT-116 and SW480 colon cancer cells reduces the ability of conditioned media derived from these cells under hypoxic conditions to promote tube formation of a human endothelial cell line (HMEC-1), a tool to assess angiogenesis pathways (Liu et al. 2018a). ORAI1-mediated SOCE drives colon cancer cell promotion of angiogenesis by hypoxia via a NOTCH1-dependent mechanism that involves the $\mathrm{Ca}^{2+}$-dependent transcription factor NFATc3 (Liu et al. 2018a). Another study highlighting the importance of studying other ion channels in angiogenesis is the work defining an important role for the stretch-activated $\mathrm{Ca}^{2+}$ channel Piezo2 in angiogenesis in a variety of models (Yang et al. 2016).

Fibroblasts and adipocytes are other components of the tumor microenvironment that can contribute to tumor progression (Bussard et al. 2016). Despite their clear importance in many cancer types, the contribution of these cells and many other stromal components to tumorigenesis has been the focus of very few studies. $\mathrm{Ca}^{2+}$ is likely to contribute to processes in carcinogenesis in these cell types. Highlighting why this is an area of potentially rich study for $\mathrm{Ca}^{2+}$ signaling researchers, a $\mathrm{Ca}^{2+}$-dependent signaling pathway is implicated in cancer-associated fibroblast (CAF)-induced drug resistance in the ovarian cancer tumor microenvironment (Leung et al. 2018). Which $\mathrm{Ca}^{2+}$ pathway was not identified however, hence this is still an area for further study. Similarly, new work has defined a role for $\mathrm{Ca}^{2+}$ signaling in CAFs in a colon cancer cell spheroid model (Stadler et al. 2017), but again the exact member(s) of the $\mathrm{Ca}^{2+}$ signaling toolkit involved remains unclear. One member of the $\mathrm{Ca}^{2+}$ signaling toolkit that is linked to CAFs in prostate cancer is TRPA1. Prostate cancer-derived CAFs express and have functional TRPA1 channels. Moreover, studies with the TRPA1 inhibitor HC-030031 (at a relatively high concentration of $50 \mu \mathrm{M}$ ) in a CAF and prostate cancer cell (LNCaP) coculture suggest a role for TRPA1 in regulating apoptotic sensitivity to resveratrol (Vancauwenberghe et al. 2017).

Adipocytes in serous ovarian cancer can activate salt-inducible kinase 2 (SIK2) in ovarian cancer cells to alter their metabolism and promote proliferation and survival (Miranda et al. 2016). Coculture experiments and intracellular $\mathrm{Ca}^{2+}$ chelation using BAPTA-AM show the importance of the $\mathrm{Ca}^{2+}$ signal in adipocyte-mediated activation of SIK2, but again the exact $\mathrm{Ca}^{2+}$ channels or pumps involved have not been defined (Miranda et al. 2016). So, although specific members of the $\mathrm{Ca}^{2+}$ signaling toolkit are linked to the tumor microenvironment in the context of immune cell function and angiogenesis, more work is required to fully define other aspects of the tumor microenvironment and their relationship with $\mathrm{Ca}^{2+}$ signaling.

\section{TARGETING THE CALCIUM-SIGNALING TOOLKIT}

Given the involvement of the $\mathrm{Ca}^{2+}$ signaling toolkit in key cancer processes, $\mathrm{Ca}^{2+}$ channels and pumps are proposed as drug targets for cancer therapeutics. In the discussion above, we highlighted examples in which silencing and/ or pharmacological modulation of $\mathrm{Ca}^{2+}$ toolkit components inhibits proliferation or metastasis in vivo, or promotes cancer cell death. Figure 3 depicts a range of potential strategies for targeting the $\mathrm{Ca}^{2+}$ signal in cancer. Either pharmacological inhibition or pharmacological activation may be appropriate approaches, depending on whether the resultant alteration to $\left[\mathrm{Ca}^{2+}\right]_{\mathrm{CYT}}$ is prodeath or prosurvival, and in some cases this dichotomous approach may be possible for the same target. TRPV4 is such a target. As discussed above, not only has TRPV4 inhibition or activation both been proposed as ways to target the tumor vasculature (Fiorio Pla et al. 2012; Adapala et al. 2016), but TRPV4 overexpression in some cancer cells could also be targeted through inhibition or activation. Inhibition of TRPV4 expression reduces metastasis of breast cancer cells that have TRPV4 overexpression in vivo (Lee et al. 2016). There may be some cases 
A

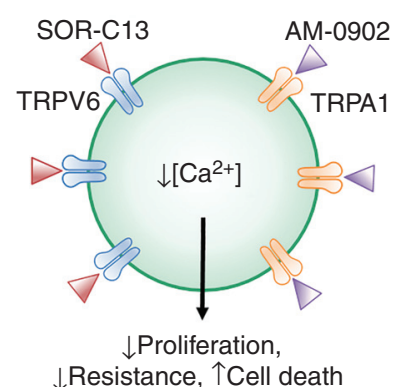

B Channel activation

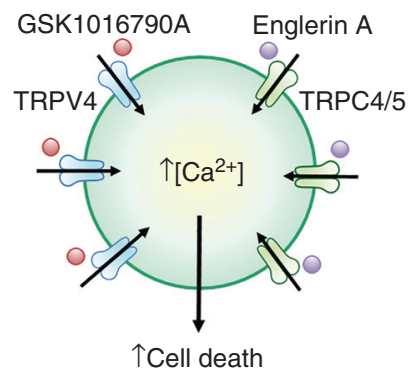

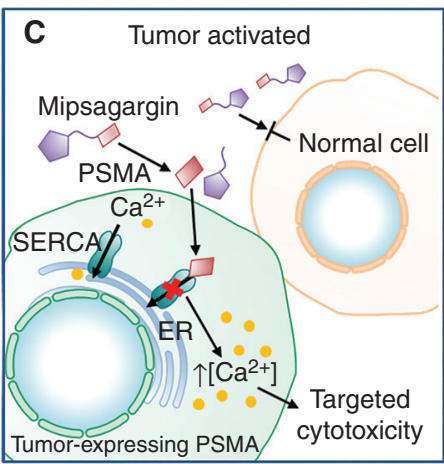
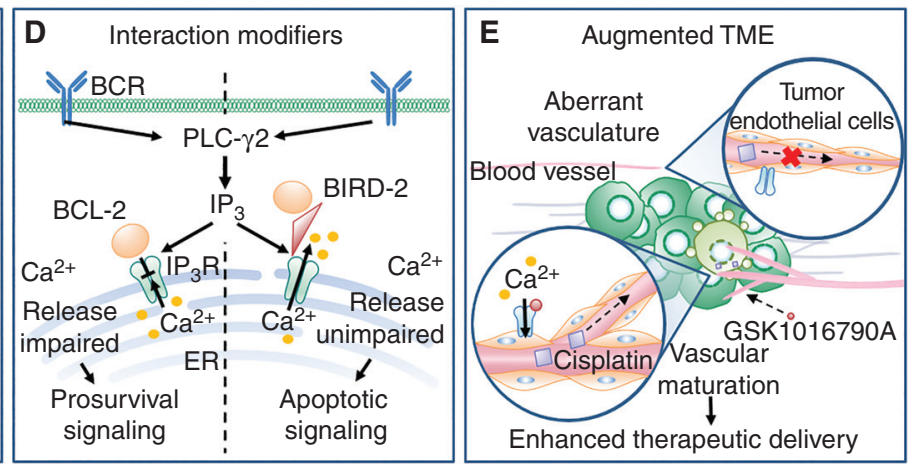

Figure 3. Selected examples of the myriad of strategies to target the $\mathrm{Ca}^{2+}$ toolkit in cancer. Pharmacological modulation of overexpressed channels can achieve a reduction in tumor progression through $(A)$ inhibition of $\mathrm{Ca}^{2+}$ channels to suppress proliferative or survival pathways, as exemplified by studies antagonizing overexpressed $\mathrm{Ca}^{2+}$-permeable channels TRPV6 and TRPA1 using selective inhibitors SOR-C13 and AM-0902, respectively (Takahashi et al. 2018; Xue et al. 2018), or (B) activation of overexpressed $\mathrm{Ca}^{2+}$-permeable channels, including TRPV4 and TRPC4/5 via GSK101670A and Englerin A, respectively, to induce cell death via multiple pathways (Akbulut et al. 2015; Peters et al. 2017). (C) Prodrug analogues of classic $\mathrm{Ca}^{2+}$ modulators use tumor activation to selectively target malignant cells. Prodrug mipsagargin cannot translocate the plasma membrane unless cleaved by prostate-specific membrane antigen (PSMA) enzyme into the membrane-permeable cytotoxic SERCA inhibitor thapsigargin. Expression of PSMA is low in normal tissues but up-regulated in some tumor microenvironments (Mahalingam et al. 2016). (D) Modification of $\mathrm{Ca}^{2+}$ channel interactions, as achieved by Bcl$2 / \mathrm{IP}_{3} \mathrm{R}$ Disruptor-2 (BIRD-2). This agent has cytotoxic capacity in cells reliant on these interactions for survival. High levels of $\mathrm{Bcl}-2$ expression can induce prosurvival signaling following B-cell receptor (BCR) activation by suppressing intracellular $\mathrm{Ca}^{2+}$ release through $\mathrm{IP}_{3} \mathrm{Rs}$. Abrogation of the $\mathrm{Bcl}-2$ and $\mathrm{IP}_{3} \mathrm{R}$ interaction by BIRD-2 can induce proapoptotic $\mathrm{Ca}^{2+}$ signaling in some lymphoma and leukemia cells (Bittremieux et al. 2018). (E) Targeting $\mathrm{Ca}^{2+}$ signaling in the tumor microenvironment can enhance chemotherapeutic potential. Cancers have aberrant vasculature formation. Activation of TRPV4 via a selective activator GSK1016790A normalizes vascular maturation by actions on endothelial cells and enhances delivery of the chemotherapeutic cisplatin, improving the efficacy of this agent (Fiorio Pla et al. 2012; Adapala et al.2016). Note that these examples are often in different cancer types.

in which TRPV4 expression is so high that its pharmacological activation may promote cell death and suppress tumor growth (Peters et al. 2017). Although the ideal target for the channelactivation approach would be one that does not contribute in any way to tumor progression (to avoid any risk of promotion of metastatic or proliferative pathways), appropriate dosing, patient selection, and combination therapies may allow for such an approach. In summary, there are diverse ways to target members of the $\mathrm{Ca}^{2+}$ toolkit in cancer, and consideration will need to 


\section{S.J. Roberts-Thomson et al.}

be made as to whether the target is in the cancer cell or cells of the tumor microenvironment, and/or whether an inhibitor or activator of the target is most appropriate.

How a member of the $\mathrm{Ca}^{2+}$ signaling toolkit is prioritized as a target for future therapy will depend on a variety of factors. This could include the risk of toxicity to normal cells, which may be predicted based on studies of pharmacological inhibitors, or when such agents are not available the phenotype of knockout mice. The degree of overexpression of the member of the $\mathrm{Ca}^{2+}$ signaling toolkit may also be a consideration. Pronounced overexpression may bestow increased sensitivity of cancer cells to an agent and allow a therapeutic window for future therapies that do not affect noncancer cells. Targets whose expression levels are related to prognosis and/or are relevant to cancer types in which therapeutic options are limited and clinical outcomes are still poor could also be prioritized. One key aspect as this field moves forward will be considerations related to combination therapies and what combinations based on mechanistic insight should be the focus of initial assessments. Given that an increasing number of studies have identified that agents currently used to treat cancer modify $\mathrm{Ca}^{2+}$ signaling, understanding the interactions on $\mathrm{Ca}^{2+}$ signaling will be important. Although this area is still relatively underexplored, examples include the ability of doxorubicin to induce changes in $\left[\mathrm{Ca}^{2+}\right]_{\mathrm{CYT}}$ in MDA-MB-231 breast cancer cells and changes in the levels of the $\mathrm{Ca}^{2+}$ channels TRPC1 and TRPC3 (Abdoul-Azize et al. 2018).

In addition to the basic concept of a direct pharmacological inhibitor or activator of a member of the $\mathrm{Ca}^{2+}$ signaling toolkit for cancer therapy, there may be other ways to exploit the $\mathrm{Ca}^{2+}$ signal in cancer therapy. Mipsagargin, a prodrug of the SERCA inhibitor thapsigargin, is converted to its active form by the prostatespecific membrane antigen enzyme, which is elevated in the tumor microenvironment of malignancies including nonprostate cancers (Mahalingam et al. 2016). Cytotoxic effects of SERCA inhibition are targeted to cancer sites because expression of the prostate-specific membrane antigen enzyme is low in normal tis- sue (Mahalingam et al. 2016). Mipsagargin has undergone phase I clinical trials in patients with refractory and advanced solid tumors (Mahalingam et al. 2016) and it adds another tool to how the $\mathrm{Ca}^{2+}$ signaling toolkit may be targeted in cancer. Another example of how future therapies may go beyond direct pharmacological activation or inhibition of $\mathrm{Ca}^{2+}$ signals is seen in the effects of the peptide $\mathrm{Bcl}-2 / \mathrm{IP}_{3} \mathrm{R}$ Disruptor-2 (BIRD-2). By disrupting Bcl-2 interactions with $\mathrm{IP}_{3} \mathrm{Rs}, \mathrm{BIRD}-2$ can convert constitutive $\mathrm{IP}_{3} \mathrm{R}$ $\mathrm{Ca}^{2+}$ release in some lymphoma and leukemia cells to a level that promotes their death (Zhong et al. 2011; Bittremieux et al. 2018). Another dimension in the targeting of cancer cells through the $\mathrm{Ca}^{2+}$ signaling toolkit is via mechanisms to prevent or reverse drug resistance to other therapies. The clearest example of this potential approach is seen in the role of TRPC5 in breast cancer multidrug resistance. TRPC5 is critical for the induction of multidrug resistance ATPase 1 (MDR-ATPase 1) expression in breast cancer cells (Ma et al. 2012). MDR-ATPase 1 is an important drug-resistance mechanism in many cancers because of its ability to efflux a diverse array of anticancer agents from the cancer cell cytoplasm. The ability of TRPC5 silencing to reduce MDR-ATPase 1 induction and reverse doxorubicin resistance in vitro and in vivo models (Ma et al. 2012), suggests that further study of other members of the $\mathrm{Ca}^{2+}$ signaling toolkit may reveal additional strategies for overcoming cancer drug resistance.

\section{CONCLUSION}

Some cancer cells appear to recruit and remodel their $\mathrm{Ca}^{2+}$ signaling toolkit to proliferate, invade, and avoid cell death. This remodeling, although not always a driver for oncogenesis, could potentially be targeted to attenuate these hallmarks of cancer. The role and importance of the $\mathrm{Ca}^{2+}$ signal in tumor progression goes beyond the cancer cell itself and may involve the regulation of the tumor microenvironment. This diversity of contributions by the $\mathrm{Ca}^{2+}$ signaling toolkit to tumor progression has resulted in specific $\mathrm{Ca}^{2+}$ channels and pumps being proposed as drug targets for individual cancer types and even sub- 
types. Indeed, clinical trials in different malignancies have begun on agents that act through the $\mathrm{Ca}^{2+}$ signal. The future should see an expansion of such trials to agents that may act more effectively in combination or those that may reverse resistance to current cancer therapies.

\section{ACKNOWLEDGMENTS}

This work was supported by the National Health and Medical Research Council (NHMRC; Project Grant 1079672) and Cancer Council Queensland (1139320). G.R.M. was supported by the Mater Foundation. The Translational Research Institute is supported by a grant from the Australian Government.

\section{REFERENCES}

Abdoul-Azize S, Buquet C, Li H, Picquenot JM, Vannier JP. 2018. Integration of $\mathrm{Ca}^{2+}$ signaling regulates the breast tumor cell response to simvastatin and doxorubicin. Oncogene 37: 4979-4993. doi:10.1038/s41388-018-0329-6

Adapala RK, Thoppil RJ, Ghosh K, Cappelli HC, Dudley AC, Paruchuri S, Keshamouni V, Klagsbrun M, Meszaros JG, Chilian WM, et al. 2016. Activation of mechanosensitive ion channel TRPV4 normalizes tumor vasculature and improves cancer therapy. Oncogene 35: 314-322. doi:10 $.1038 /$ onc. 2015.83

Akbulut Y, Gaunt HJ, Muraki K, Ludlow MJ, Amer MS, Bruns A, Vasudev NS, Radtke L, Willot M, Hahn S, et al. 2015. (-)-Englerin $A$ is a potent and selective activator of TRPC4 and TRPC5 calcium channels. Angew Chem Int Ed Engl 54: 3787-3791. doi:10.1002/anie.201411511

Aydar E, Yeo S, Djamgoz M, Palmer C. 2009. Abnormal expression, localization and interaction of canonical transient receptor potential ion channels in human breast cancer cell lines and tissues: A potential target for breast cancer diagnosis and therapy. Cancer Cell Int 9: 23. doi:10 1186/1475-2867-9-23

Azimi I, Roberts-Thomson SJ, Monteith GR. 2014. Calcium influx pathways in breast cancer: Opportunities for pharmacological intervention. Br J Pharmacol 171: 945-960. doi:10.1111/bph.12486

Azimi I, Beilby H, Davis FM, Marcial DL, Kenny PA, Thompson EW, Roberts-Thomson SJ, Monteith GR. 2016. Altered purinergic receptor-Ca ${ }^{2+}$ signaling associated with hypoxia-induced epithelial-mesenchymal transition in breast cancer cells. Mol Oncol 10: 166-178. doi:10.1016/j.molonc.2015.09.006

Azimi I, Flanagan JU, Stevenson RJ, Inserra M, Vetter I, Monteith GR, Denny WA. 2017. Evaluation of known and novel inhibitors of Orail-mediated store operated $\mathrm{Ca}^{2+}$ entry in MDA-MB-231 breast cancer cells using a fluorescence imaging plate reader assay. Bioorg Med Chem 25: 440-449. doi:10.1016/j.bmc.2016.11.007
Azimi I, Bong AH, Poo GXH, Armitage K, Lok D, RobertsThomson SJ, Monteith GR. 2018. Pharmacological inhibition of store-operated calcium entry in MDA-MB-468 basal A breast cancer cells: Consequences on calcium signalling, cell migration and proliferation. Cell Mol Life Sci 75: 4525-4537. doi: 10.1007/s00018-018-2904-y

Azimi I, Milevskiy MJG, Chalmers SB, Yapa K, Robitaille M, Henry C, Baillie GJ, Thompson EW, Roberts-Thomson SJ, Monteith GR. 2019. ORAI1 and ORAI3 in breast cancer molecular subtypes and the identification of ORAI3 as a hypoxia sensitive gene and a regulator of hypoxia responses. Cancers (Basel) 11: E208. doi:10.3390/can cers11020208

Badaoui M, Mimsy-Julienne C, Saby C, Van Gulick L, Peretti M, Jeannesson P, Morjani H, Ouadid-Ahidouch H. 2018. Collagen type 1 promotes survival of human breast cancer cells by overexpressing Kv10.1 potassium and Orail calcium channels through DDR1-dependent pathway. Oncotarget 9: 24653-24671. doi:10.18632/oncotarget.19065

Berridge MJ. 1997. The AM and FM of calcium signalling. Nature 386: 759-760. doi:10.1038/386759a0

Berridge MJ, Bootman MD, Roderick HL. 2003. Calcium signalling: Dynamics, homeostasis and remodelling. Nat Rev Mol Cell Biol 4: 517-529. doi:10.1038/nrm1155

Bissell MJ, Hines WC. 2011. Why don't we get more cancer? A proposed role of the microenvironment in restraining cancer progression. Nat Med 17: 320-329. doi:10.1038/ nm. 2328

Bittremieux M, Parys JB, Pinton P, Bultynck G. 2016. ER functions of oncogenes and tumor suppressors: Modulators of intracellular $\mathrm{Ca}^{2+}$ signaling. Mol Cell Res 1863: 1364-1378. doi:10.1016/j.bbamcr.2016.01.002

Bittremieux M, La Rovere RM, Akl H, Martines C, Welkenhuyzen K, Dubron K, Baes M, Janssens A, Vandenberghe $\mathrm{P}$, Laurenti L, et al. 2018. Constitutive $\mathrm{IP}_{3}$ signaling underlies the sensitivity of $\mathrm{B}$-cell cancers to the $\mathrm{Bcl}-2 / \mathrm{IP}_{3}$ receptor disruptor BIRD-2. Cell Death Differ 26: 531547. doi:10.1038/s41418-018-0142-3

Bolanz KA, Hediger MA, Landowski CP. 2008. The role of TRPV6 in breast carcinogenesis. Mol Cancer Ther 7: 271279. doi:10.1158/1535-7163.MCT-07-0478

Bong AHL, Monteith GR. 2018. Calcium signaling and the therapeutic targeting of cancer cells. Biochim Biophys Acta Mol Cell Res 1865: 1786-1794. doi: 10.1016/j .bbamcr.2018.05.015

Bononi A, Giorgi C, Patergnani S, Larson D, Verbruggen K, Tanji M, Pellegrini L, Signorato V, Olivetto F, Pastorino S, et al. 2017. BAP1 regulates $\mathrm{IP}_{3} \mathrm{R} 3$-mediated $\mathrm{Ca}^{2+}$ flux to mitochondria suppressing cell transformation. Nature 546: 549-553. doi:10.1038/nature22798

Bonora M, Giorgi C, Pinton P. 2015. Novel frontiers in calcium signaling: A possible target for chemotherapy. Pharmacol Res 99: 82-85. doi:10.1016/j.phrs.2015.05.008

Bootman MD, Collins TJ, Peppiatt CM, Prothero LS, MacKenzie L, De Smet P, Travers M, Tovey SC, Seo JT, Berridge MJ, et al. 2001. Calcium signalling-An overview. Semin Cell Dev Biol 12: 3-10. doi:10.1006/scdb.2000.0211

Boudreau A, van't Veer LJ, Bissell MJ. 2012. An "elite hacker": Breast tumors exploit the normal microenvironment program to instruct their progression and biological diversity. Cell Adh Migr 6: 236-248. doi:10.4161/cam .20880 


\section{S.J. Roberts-Thomson et al.}

Bultynck G, Parys JB. 2018. Ca ${ }^{2+}$ signaling and cell death Focus on $\mathrm{Ca}^{2+}$-transport systems and their implication in cell death and survival. Cell Calcium 69: 1-3. doi:10.1016/ j.ceca.2017.09.001

Bussard KM, Mutkus L, Stumpf K, Gomez-Manzano C, Marini FC. 2016. Tumor-associated stromal cells as key contributors to the tumor microenvironment. Breast Cancer Res 18: 84. doi:10.1186/s13058-016-0740-2

Carafoli E. 2002. Calcium signaling: A tale for all seasons Proc Natl Acad Sci 99: 1115-1122. doi:10.1073/pnas .032427999

Cárdenas C, Miller RA, Smith I, Bui T, Molgó J, Müller M, Vais H, Cheung KH, Yang J, Parker I, et al. 2010. Essential regulation of cell bioenergetics by constitutive InsP3 receptor $\mathrm{Ca}^{2+}$ transfer to mitochondria. Cell 142: 270-283. doi:10.1016/j.cell.2010.06.007

Cárdenas C, Müller M, McNeal A, Lovy A, Jaňa F, Bustos G Urra F, Smith N, Molgó J, Diehl JA, et al. 2016. Selective vulnerability of cancer cells by inhibition of $\mathrm{Ca}^{2+}$ transfer from endoplasmic reticulum to mitochondria. Cell Rep 14: 2313-2324. doi:10.1016/j.celrep.2016.02.030

Chen YF, Chiu WT, Chen YT, Lin PY, Huang HJ, Chou CY, Chang HC, Tang MJ, Shen MR. 2011. Calcium store sensor stromal-interaction molecule 1-dependent signaling plays an important role in cervical cancer growth, migration, and angiogenesis. Proc Natl Acad Sci 108: 1522515230. doi:10.1073/pnas.1103315108

Curry MC, Luk NA, Kenny PA, Roberts-Thomson SJ, Monteith GR. 2012. Distinct regulation of cytoplasmic calcium signals and cell death pathways by different plasma membrane calcium ATPase isoforms in MDA-MB-231 breast cancer cells. J Biol Chem 287: 28598-28608. doi:10.1074/ jbc.M112.364737

Curry MC, Peters AA, Kenny PA, Roberts-Thomson SJ, Monteith GR. 2013. Mitochondrial calcium uniporter silencing potentiates caspase-independent cell death in MDA-MB-231 breast cancer cells. Biochem Biophys Res Commun 434: 695-700. doi:10.1016/j.bbrc.2013.04.015

Curry M, Roberts-Thomson SJ, Monteith GR. 2016. PMCA2 silencing potentiates MDA-MB-231 breast cancer cell death initiated with the Bcl-2 inhibitor ABT-263. Biochem Biophys Res Commun 478: 1792-1797. doi:10 .1016/j.bbrc.2016.09.030

Danese A, Patergnani S, Bonora M, Wieckowski MR, Previati M, Giorgi C, Pinton P. 2017. Calcium regulates cell death in cancer: Roles of the mitochondria and mitochondria-associated membranes (MAMs). Biochim Biophys Acta Bioenerg 1858: 615-627. doi:10.1016/j.bbabio.2017 .01 .003

Davis FM, Kenny PA, Soo ET, van Denderen BJ, Thompson EW, Cabot PJ, Parat MO, Roberts-Thomson SJ, Monteith GR. 2011. Remodeling of purinergic receptor-mediated $\mathrm{Ca}^{2+}$ signaling as a consequence of EGF-induced epithelial-mesenchymal transition in breast cancer cells. PLoS ONE 6: e23464. doi:10.1371/journal.pone.0023464

Davis FM, Peters AA, Grice DM, Cabot PJ, Parat MO, Roberts-Thomson SJ, Monteith GR. 2012. Non-stimulated, agonist-stimulated and store-operated $\mathrm{Ca}^{2+}$ influx in MDA-MB-468 breast cancer cells and the effect of EGFinduced EMT on calcium entry. PLoS ONE 7: e36923. doi:10.1371/journal.pone.0036923
Davis FM, Parsonage MT, Cabot PJ, Parat MO, Thompson EW, Roberts-Thomson SJ, Monteith GR. 2013. Assessment of gene expression of intracellular calcium channels, pumps and exchangers with epidermal growth factorinduced epithelial-mesenchymal transition in a breast cancer cell line. Cancer Cell Int 13: 76. doi:10.1186/ 1475-2867-13-76

Davis FM, Azimi I, Faville RA, Peters AA, Jalink K, Putney JW Jr, Goodhill GJ, Thompson EW, Roberts-Thomson SJ, Monteith GR. 2014a. Induction of epithelialmesenchymal transition (EMT) in breast cancer cells is calcium signal dependent. Oncogene 33: 2307-2316. doi:10.1038/onc.2013.187

Davis FM, Stewart TA, Thompson EW, Monteith GR. 2014b. Targeting EMT in cancer: Opportunities for pharmacological intervention. Trends Pharmacol Sci 35: 479-488. doi:10.1016/j.tips.2014.06.006

Diez-Bello R, Jardin I, Salido GM, Rosado JA. 2017. Orail and Orai2 mediate store-operated calcium entry that regulates HL60 cell migration and FAK phosphorylation. Biochim Biophys Acta 1864: 1064-1070. doi:10.1016/j .bbamcr.2016.11.014

Ding X, He Z, Zhou K, Cheng J, Yao H, Lu D, Cai R, Jin Y, Dong B, Xu Y, et al. 2010. Essential role of TRPC6 channels in $\mathrm{G}_{2} / \mathrm{M}$ phase transition and development of human glioma. J Natl Cancer Inst 102: 1052-1068. doi:10.1093/ jnci/djq217

Dubois C, Vanden Abeele F, Prevarskaya N. 2013. Targeting apoptosis by the remodelling of calcium-transporting proteins in cancerogenesis. FEBS J 280: 5500-5510. doi:10.1111/febs.12246

Dubois C, Vanden Abeele F, Lehen'kyi V, Gkika D, Guarmit B, Lepage G, Slomianny C, Borowiec AS, Bidaux G, Benahmed M, et al. 2014. Remodeling of channel-forming ORAI proteins determines an oncogenic switch in prostate cancer. Cancer Cell 26: 19-32. doi:10.1016/j.ccr .2014 .04 .025

El Hiani Y, Lehen'kyi V, Ouadid-Ahidouch H, Ahidouch A. 2009. Activation of the calcium-sensing receptor by high calcium induced breast cancer cell proliferation and TRPC1 cation channel over-expression potentially through EGFR pathways. Arch Biochem Biophys 486: 58-63. doi:10.1016/j.abb.2009.03.010

Falk H, Matthiessen LW, Wooler G, Gehl J. 2018. Calcium electroporation for treatment of cutaneous metastases; a randomized double-blinded phase II study, comparing the effect of calcium electroporation with electrochemotherapy. Acta Oncol 57: 311-319. doi:10.1080/0284186X .2017.1355109

Faouzi M, Kischel P, Hague F, Ahidouch A, Benzerdjeb N, Sevestre H, Penner R, Ouadid-Ahidouch H. 2013. ORAI3 silencing alters cell proliferation and cell cycle progression via c-myc pathway in breast cancer cells. Biochim Biophys Acta 1833: 752-760. doi:10.1016/j.bbamcr.2012 .12 .009

Faouzi M, Hague F, Geerts D, Ay AS, Potier-Cartereau M, Ahidouch A, Ouadid-Ahidouch H. 2016. Functional cooperation between KCa3.1 and TRPC1 channels in human breast cancer: Role in cell proliferation and patient prognosis. Oncotarget 7: 36419-36435. doi:10.18632/on cotarget.9261 
Feng M, Grice DM, Faddy HM, Nguyen N, Leitch S, Wang Y, Muend S, Kenny PA, Sukumar S, Roberts-Thomson SJ, et al. 2010. Store-independent activation of Orail by SPCA2 in mammary tumors. Cell 143: 84-98. doi:10.1016/j.cell .2010 .08 .040

Fiorio Pla A, Ong HL, Cheng KT, Brossa A, Bussolati B, Lockwich T, Paria B, Munaron L, Ambudkar IS. 2012. TRPV4 mediates tumor-derived endothelial cell migration via arachidonic acid-activated actin remodeling. Oncogene 31: 200-212. doi:10.1038/onc.2011.231

Fixemer T, Wissenbach U, Flockerzi V, Bonkhoff H. 2003. Expression of the $\mathrm{Ca}^{2+}$-selective cation channel TRPV6 in human prostate cancer: A novel prognostic marker for tumor progression. Oncogene 22: 7858-7861. doi:10 $.1038 /$ sj.onc. 1206895

Fornaro L, Vivaldi C, Lin D, Xue H, Falcone A, Wang Y, Crea F, Bootman MD. 2017. Prognostic relevance of a T-type calcium channels gene signature in solid tumours: A correlation ready for clinical validation. PLOS ONE 12: e0182818. doi:10.1371/journal.pone.0182818

Frandsen SK, Gissel H, Hojman P, Tramm T, Eriksen J, Gehl J. 2012. Direct therapeutic applications of calcium electroporation to effectively induce tumor necrosis. Cancer Res 72: 1336-1341. doi:10.1158/0008-5472.CAN-113782

Frandsen SK, Krüger MB, Mangalanathan UM, Tramm T, Mahmood F, Novak I, Gehl J. 2017. Normal and malignant cells exhibit differential responses to calcium electroporation. Cancer Res 77: 4389-4401. doi:10.1158/ 0008-5472.CAN-16-1611

Frischauf I, Litviňuková M, Schober R, Zayats V, Svobodová B, Bonhenry D, Lunz V, Cappello S, Tociu L, Reha D, et al. 2017. Transmembrane helix connectivity in Orail controls two gates for calcium-dependent transcription. Sci Signal 10: eaao0358. doi:10.1126/scisignal.aao0358

Fu S, Hirte H, Welch S, Ilenchuk TT, Lutes T, Rice C, Fields N, Nemet A, Dugourd D, Piha-Paul S, et al. 2017. First-inhuman phase I study of SOR-C13, a TRPV6 calcium channel inhibitor, in patients with advanced solid tumors. Invest New Drugs 35: 324-333. doi:10.1007/s10637-0170438-z

Gershkovitz M, Caspi Y, Fainsod-Levi T, Katz B, Michaeli J, Khawaled S, Lev S, Polyansky L, Shaul ME, Sionov RV, et al. 2018a. TRPM2 mediates neutrophil killing of disseminated tumor cells. Cancer Res 78: 2680-2690. doi:10 .1158/0008-5472.CAN-17-3614

Gershkovitz M, Fainsod-Levi T, Khawaled S, Shaul ME, Sionov RV, Cohen-Daniel L, Aqeilan RI, Shaul YD, Fridlender ZG, Granot Z. 2018b. Microenvironmental cues determine tumor cell susceptibility to neutrophil cytotoxicity. Cancer Res 78: 5050-5059. doi:10.1158/0008-5472 .CAN-18-0540

Gershkovitz M, Fainsod-Levi T, Zelter T, Sionov RV, Granot Z. 2018c. TRPM2 modulates neutrophil attraction to murine tumor cells by regulating CXCL2 expression. Cancer Immunol Immunother 68: 33-43. doi:10.1007/s00262018-2249-2

Giacomello M, Drago I, Pizzo P, Pozzan T. 2007. Mitochondrial $\mathrm{Ca}^{2+}$ as a key regulator of cell life and death. Cell Death Differ 14: 1267-1274. doi:10.1038/sj.cdd.4402147

Giorgi C, Bonora M, Sorrentino G, Missiroli S, Poletti F, Suski JM, Ramirez FG, Rizzuto R, Di Virgilio F, Zito E, et al. 2015. p53 at the endoplasmic reticulum regulates apoptosis in a $\mathrm{Ca}^{2+}$-dependent manner. Proc Natl Acad Sci 112: 1779-1784. doi:10.1073/pnas.1410723112

Grasset EM, Bertero T, Bozec A, Friard J, Bourget I, Pisano S, Lecacheur M, Maiel M, Bailleux C, Emelyanov A, et al. 2018. Matrix stiffening and EGFR cooperate to promote the collective invasion of cancer cells. Cancer Res 78: 5229-5242. doi:10.1158/0008-5472.CAN-18-0601

Gueguinou M, Crottès D, Chantôme A, Rapetti-Mauss R, Potier-Cartereau M, Clarysse L, Girault A, Fourbon Y, Jézéquel P, Guérin-Charbonnel C, et al. 2017. The SigmaR1 chaperone drives breast and colorectal cancer cell migration by tuning SK3-dependent $\mathrm{Ca}^{2+}$ homeostasis. Oncogene 36: 3640-3647. doi:10.1038/onc.2016.501

Guilbert A, Dhennin-Duthille I, Hiani YE, Haren N, Khorsi H, Sevestre H, Ahidouch A, Ouadid-Ahidouch H. 2008 Expression of TRPC6 channels in human epithelial breast cancer cells. BMC Cancer 8: 125. doi:10.1186/1471-24078-125

Guilbert A, Gautier M, Dhennin-Duthille I, Haren N, Sevestre H, Ouadid-Ahidouch H. 2009. Evidence that TRPM7 is required for breast cancer cell proliferation. Am J Physiol Cell Physiol 297: C493-C502. doi:10.1152/ ajpcell.00624.2008

Hammadi M, Chopin V, Matifat F, Dhennin-Duthille I, Chasseraud M, Sevestre H, Ouadid-Ahidouch H. 2012. Human ether a-gogo $\mathrm{K}^{+}$channel 1 (hEag1) regulates MDA-MB-231 breast cancer cell migration through Orail-dependent calcium entry. J Cell Physiol 227: 3837-3846. doi:10.1002/jcp.24095

Hanahan D, Weinberg RA. 2000. The hallmarks of cancer. Cell 100: 57-70. doi:10.1016/S0092-8674(00)81683-9

Hanahan D, Weinberg RA. 2011. Hallmarks of cancer: The next generation. Cell 144: 646-674. doi:10.1016/j.cell 2011.02.013

Hasna J, Hague F, Rodat-Despoix L, Geerts D, Leroy C, Tulasne D, Ouadid-Ahidouch H, Kischel P. 2018. Orai3 calcium channel and resistance to chemotherapy in breast cancer cells: The p53 connection. Cell Death Differ 25: 691-705. doi:10.1038/s41418-017-0007-1

Hegedũs L, Garay T, Molnár E, Varga K, Bilecz A, Török S, Padányi R, Pászty K, Wolf M, Grusch M, et al. 2017. The plasma membrane $\mathrm{Ca}^{2+}$ pump PMCA4b inhibits the migratory and metastatic activity of BRAF mutant melanoma cells. Int J Cancer 140: 2758-2770. doi:10.1002/ijc .30503

Hopkins MM, Feng X, Liu M, Parker LP, Koh DW. 2015. Inhibition of the transient receptor potential melastatin-2 channel causes increased DNA damage and decreased proliferation in breast adenocarcinoma cells. Int J Oncol 46: 2267-2276. doi:10.3892/ijo.2015.2919

Ivanova H, Kerkhofs M, La Rovere RM, Bultynck G. 2017. Endoplasmic reticulum-mitochondrial $\mathrm{Ca}^{2+}$ fluxes underlying cancer cell survival. Front Oncol 7: 70. doi:10 $.3389 /$ fonc. 2017.00070

Jin Y, Cui D, Ren J, Wang K, Zeng T, Gao L. 2017. CACNA2D3 is downregulated in gliomas and functions as a tumor suppressor. Mol Carcinog 56: 945-959. doi:10 $.1002 / \mathrm{mc} .22548$

Kar P, Parekh AB. 2015. Distinct spatial $\mathrm{Ca}^{2+}$ signatures selectively activate different NFAT transcription factor 


\section{S.J. Roberts-Thomson et al.}

isoforms. Mol Cell 58: 232-243. doi:10.1016/j.molcel 2015.02.027

Kenny PA, Lee GY, Bissell MJ. 2007. Targeting the tumor microenvironment. Front Biosci 12: 3468-3474. doi:10 $.2741 / 2327$

Kerkhofs M, Giorgi C, Marchi S, Seitaj B, Parys JB, Pinton P, Bultynck G, Bittremieux M. 2017. Alterations in $\mathrm{Ca}^{2+}$ signalling via ER-mitochondria contact site remodelling in cancer. Adv Exp Med Biol 997: 225-254. doi:10.1007/ 978-981-10-4567-7_17

Kerkhofs M, Bittremieux M, Morciano G, Giorgi C, Pinton P, Parys JB, Bultynck G. 2018. Emerging molecular mechanisms in chemotherapy: $\mathrm{Ca}^{2+}$ signaling at the mitochondria-associated endoplasmic reticulum membranes. Cell Death Dis 9: 334. doi:10.1038/s41419-017-0179-0

Kim BJ. 2012. Involvement of transient receptor potential melastatin 7 channels in sophorae radix-induced apoptosis in cancer cells: Sophorae Radix and TRPM7. J Pharmacopuncture 15: 31-38. doi:10.3831/KPI.2012.15.003

Kim JH, Lkhagvadorj S, Lee MR, Hwang KH, Chung HC, Jung JH, Cha SK, Eom M. 2014. Orail and STIM1 are critical for cell migration and proliferation of clear cell renal cell carcinoma. Biochem Biophys Res Commun 448: 76-82. doi:10.1016/j.bbrc.2014.04.064

Koh DW, Powell DP, Blake SD, Hoffman JL, Hopkins MM, Feng X. 2015. Enhanced cytotoxicity in triple-negative and estrogen receptor-positive breast adenocarcinoma cells due to inhibition of the transient receptor potential melastatin-2 channel. Oncol Rep 34: 1589-1598. doi:10 .3892/or.2015.4131

Kuchay S, Giorgi C, Simoneschi D, Pagan J, Missiroli S, Saraf A, Florens L, Washburn MP, Collazo-Lorduy A, CastilloMartin M, et al. 2017. PTEN counteracts FBXL2 to promote $\mathrm{IP}_{3} \mathrm{R} 3$ - and $\mathrm{Ca}^{2+}$-mediated apoptosis limiting tumour growth. Nature 546: 554-558. doi:10.1038/na ture22965

La Rovere RM, Roest G, Bultynck G, Parys JB. 2016. Intracellular $\mathrm{Ca}^{2+}$ signaling and $\mathrm{Ca}^{2+}$ microdomains in the control of cell survival, apoptosis and autophagy. Cell Calcium 60: 74-87. doi:10.1016/j.ceca.2016.04.005

Lastraioli E, Iorio J, Arcangeli A. 2015. Ion channel expression as promising cancer biomarker. Biochim Biophys Acta 1848: 2685-2702. doi:10.1016/j.bbamem.2014.12 .016

Lee JM, Davis FM, Roberts-Thomson SJ, Monteith GR. 2011. Ion channels and transporters in cancer. 4. Remodeling of $\mathrm{Ca}^{2+}$ signaling in tumorigenesis: Role of $\mathrm{Ca}^{2+}$ transport. Am J Physiol Cell Physiol 301: C969-C976. doi:10.1152/ajpcell.00136.2011

Lee WH, Choong LY, Mon NN, Lu S, Lin Q, Pang B, Yan B, Krishna VS, Singh H, Tan TZ, et al. 2016. TRPV4 regulates breast cancer cell extravasation, stiffness and actin cortex. Sci Rep 6: 27903. doi:10.1038/srep27903

Leung CS, Yeung TL, Yip KP, Wong KK, Ho SY, Mangala LS, Sood AK, Lopez-Berestein G, Sheng J, Wong ST, et al 2018. Cancer-associated fibroblasts regulate endothelial adhesion protein LPP to promote ovarian cancer chemoresistance. J Clin Invest 128: 589-606. doi:10.1172/ JCI95200

Li C, Rezania S, Kammerer S, Sokolowski A, Devaney T, Gorischek A, Jahn S, Hackl H, Groschner K, Windpassinger C, et al. 2015. Piezol forms mechanosensitive ion channels in the human MCF-7 breast cancer cell line. Sci Rep 5: 8364. doi:10.1038/srep08364

Liu J, Chen Y, Shuai S, Ding D, Li R, Luo R. 2014. TRPM8 promotes aggressiveness of breast cancer cells by regulating EMT via activating AKT/GSK-3 $\beta$ pathway. Tumour Biol 35: 8969-8977. doi:10.1007/s13277-014-2077-8

Liu X, Wan X, Kan H, Wang Y, Yu F, Feng L, Jin J, Zhang P, Ma X. 2018a. Hypoxia-induced upregulation of Orail drives colon cancer invasiveness and angiogenesis. Eur J Pharmacol 832: 1-10. doi:10.1016/j.ejphar.2018.05.008

Liu X, Wang T, Wang Y, Chen Z, Hua D, Yao X, Ma X, Zhang P. 2018b. Orail is critical for Notch-driven aggressiveness under hypoxic conditions in triple-negative breast cancers. Biochim Biophys Acta 1864: 975-986. doi:10.1016/j .bbadis.2018.01.003

Ma X, Cai Y, He D, Zou C, Zhang P, Lo CY, Xu Z, Chan FL, Yu S, Chen Y, et al. 2012. Transient receptor potential channel TRPC5 is essential for P-glycoprotein induction in drug-resistant cancer cells. Proc Natl Acad Sci 109: 16282-16287. doi:10.1073/pnas.1202989109

Ma X, Chen Z, Hua D, He D, Wang L, Zhang P, Wang J, Cai Y, Gao C, Zhang X, et al. 2014. Essential role for TrpC5containing extracellular vesicles in breast cancer with chemotherapeutic resistance. Proc Natl Acad Sci 111: 6389-6394. doi:10.1073/pnas.1400272111

Mahalingam D, Wilding G, Denmeade S, Sarantopoulas J, Cosgrove D, Cetnar J, Azad N, Bruce J, Kurman M, Allgood VE, et al. 2016. Mipsagargin, a novel thapsigarginbased PSMA-activated prodrug: Results of a first-in-man phase I clinical trial in patients with refractory, advanced or metastatic solid tumours. Br J Cancer 114: 986-994. doi:10.1038/bjc.2016.72

Mahdi SH, Cheng H, Li J, Feng R. 2015. The effect of TGF- $\beta$ induced epithelial-mesenchymal transition on the expression of intracellular calcium-handling proteins in T47D and MCF-7 human breast cancer cells. Arch Biochem Biophys 583: 18-26. doi:10.1016/j.abb.2015.07.008

Mao Y, Keller ET, Garfield DH, Shen K, Wang J. 2013. Stromal cells in tumor microenvironment and breast cancer. Cancer Metastasis Rev 32: 303-315. doi:10.1007/s10555012-9415-3

Marchi S, Giorgi C, Oparka M, Duszynski J, Wieckowski MR, Pinton P. 2014. Oncogenic and oncosuppressive signal transduction at mitochondria-associated endoplasmic reticulum membranes. Mol Cell Oncol 1: e956469. doi:10.4161/23723548.2014.956469

Martinac B, Poole K. 2018. Mechanically activated ion channels. Int J Biochem Cell Biol 97: 104-107. doi:10.1016/j biocel.2018.02.011

Milella M, Falcone I, Conciatori F, Cesta Incani U, Del Curatolo A, Inzerilli N, Nuzzo CM, Vaccaro V, Vari S, Cognetti F, et al. 2015. PTEN: Multiple functions in human malignant tumors. Front Oncol 5: 24. doi:10.3389/fonc 2015.00024

Miranda F, Mannion D, Liu S, Zheng Y, Mangala LS, Redondo C, Herrero-Gonzalez S, Xu R, Taylor C, Chedom DF, et al. 2016. Salt-inducible kinase 2 couples ovarian cancer cell metabolism with survival at the adipocyte-rich metastatic niche. Cancer Cell 30: 273-289. doi:10.1016/j.ccell .2016 .06 .020 
Monteith GR, McAndrew D, Faddy HM, Roberts-Thomson SJ. 2007. Calcium and cancer: Targeting $\mathrm{Ca}^{2+}$ transport. Nat Rev Cancer 7: 519-530. doi:10.1038/nrc2171

Monteith GR, Davis FM, Roberts-Thomson SJ. 2012. Calcium channels and pumps in cancer: Changes and consequences. J Biol Chem 287: 31666-31673. doi:10.1074/jbc .R112.343061

Monteith GR, Prevarskaya N, Roberts-Thomson SJ. 2017. The calcium-cancer signalling nexus. Nat Rev Cancer 17: 367-380. doi:10.1038/nrc.2017.18

Motiani RK, Abdullaev IF, Trebak M. 2010. A novel native store-operated calcium channel encoded by Orai3: Selective requirement of Orai3 versus Orail in estrogen receptor-positive versus estrogen receptor-negative breast cancer cells. J Biol Chem 285: 19173-19183. doi:10.1074/ jbc.M110.102582

Motiani RK, Zhang X, Harmon KE, Keller RS, Matrougui K, Bennett JA, Trebak M. 2013. Orai3 is an estrogen receptor $\alpha$-regulated $\mathrm{Ca}^{2+}$ channel that promotes tumorigenesis. FASEB J 27: 63-75. doi:10.1096/fj.12-213801

Mound A, Vautrin-Glabik A, Foulon A, Botia B, Hague F, Parys JB, Ouadid-Ahidouch H, Rodat-Despoix L. 2017. Downregulation of type 3 inositol $(1,4,5)$-trisphosphate receptor decreases breast cancer cell migration through an oscillatory $\mathrm{Ca}^{2+}$ signal. Oncotarget 8: 72324-72341. doi:10.18632/oncotarget.20327

Ohkubo T, Yamazaki J. 2012. T-type voltage-activated calcium channel Cav3.1, but not Cav3.2, is involved in the inhibition of proliferation and apoptosis in MCF-7 human breast cancer cells. Int J Oncol 41: 267-275. doi:10 .3892/ijo.2012.1422

Pardo-Pastor C, Rubio-Moscardo F, Vogel-Gonzalez M, Serra SA, Afthinos A, Mrkonjic S, Destaing O, Abenza JF, Fernández-Fernández JM, Trepat X, et al. 2018. Piezo2 channel regulates RhoA and actin cytoskeleton to promote cell mechanobiological responses. Proc Natl Acad Sci 115: 1925-1930. doi:10.1073/pnas.1718177115

Parys JB, Bultynck G. 2018. $\mathrm{Ca}^{2+}$ signaling and cell death: Focus on the role of $\mathrm{Ca}^{2+}$ signals in the regulation of cell death \& survival processes in health, disease and therapy. Cell Calcium 70: 1-2. doi:10.1016/j.ceca.2017.11.003

Pedersen SF, Owsianik G, Nilius B. 2005. TRP channels: An overview. Cell Calcium 38: 233-252. doi:10.1016/j.ceca 2005.06.028

Peters AA, Simpson PT, Bassett JJ, Lee JM, Da Silva L, Reid LE, Song S, Parat MO, Lakhani SR, Kenny PA, et al. 2012. Calcium channel TRPV6 as a potential therapeutic target in estrogen receptor-negative breast cancer. $\mathrm{Mol}$ Cancer Ther 11: 2158-2168. doi:10.1158/1535-7163.MCT-110965

Peters AA, Milevskiy MJ, Lee WC, Curry MC, Smart CE, Saunus JM, Reid L, da Silva L, Marcial DL, Dray E, et al. 2016. The calcium pump plasma membrane $\mathrm{Ca}^{2+}$ ATPase 2 (PMCA2) regulates breast cancer cell proliferation and sensitivity to doxorubicin. Sci Rep 6: 25505 . doi:10.1038/srep25505

Peters AA, Jamaludin SYN, Yapa K, Chalmers S, Wiegmans AP, Lim HF, Milevskiy MJG, Azimi I, Davis FM, Northwood KS, et al. 2017. Oncosis and apoptosis induction by activation of an overexpressed ion channel in breast cancer cells. Oncogene 36: 6490-6500. doi:10.1038/onc .2017 .234
Pierro C, Cook SJ, Foets TCF, Bootman MD, Roderick HL 2014. Oncogenic K-Ras suppresses $\mathrm{IP}_{3}$-dependent $\mathrm{Ca}^{2+}$ release through remodelling of the isoform composition of $\mathrm{IP}_{3} \mathrm{Rs}$ and ER luminal $\mathrm{Ca}^{2+}$ levels in colorectal cancer cell lines. J Cell Sci 127: 1607-1619. doi:10.1242/jcs .141408

Pierro C, Zhang X, Kankeu C, Trebak M, Bootman MD, Roderick HL. 2018. Oncogenic KRAS suppresses storeoperated $\mathrm{Ca}^{2+}$ entry and ICRAC through ERK pathwaydependent remodelling of STIM expression in colorectal cancer cell lines. Cell Calcium 72: 70-80. doi:10.1016/j ceca.2018.03.002

Prevarskaya N, Skryma R, Shuba Y. 2011. Calcium in tumour metastasis: New roles for known actors. Nat Rev Cancer 11: 609-618. doi:10.1038/nrc3105

Prior IA, Lewis PD, Mattos C. 2012. A comprehensive survey of Ras mutations in cancer. Cancer Res 72: 2457-2467. doi:10.1158/0008-5472.CAN-11-2612

Qi L, Song W, Li L, Cao L, Yu Y, Song C, Wang Y, Zhang F, Li Y, Zhang B, et al. 2016. FGF4 induces epithelialmesenchymal transition by inducing store-operated calcium entry in lung adenocarcinoma. Oncotarget 7: 74015-74030. doi:10.18632/oncotarget.12187

Ren T, Zhang H, Wang J, Zhu J, Jin M, Wu Y, Guo X, Ji L, Huang Q, Zhang H, et al. 2017. MCU-dependent mitochondrial $\mathrm{Ca}^{2+}$ inhibits $\mathrm{NAD}^{+} /$SIRT3/SOD2 pathway to promote ROS production and metastasis of HCC cells. Oncogene 36: 5897-5909. doi:10.1038/onc.2017.167

Rizzuto R, Pinton P, Ferrari D, Chami M, Szabadkai G, Magalhães PJ, Di Virgilio F, Pozzan T. 2003. Calcium and apoptosis: Facts and hypotheses. Oncogene 22: 8619-8627. doi:10.1038/sj.onc.1207105

Rizzuto R, De Stefani D, Raffaello A, Mammucari C. 2012. Mitochondria as sensors and regulators of calcium signalling. Nat Rev Mol Cell Biol 13: 566-578. doi:10.1038/ nrm3412

Roderick HL, Cook SJ. 2008. $\mathrm{Ca}^{2+}$ signalling checkpoints in cancer: Remodelling $\mathrm{Ca}^{2+}$ for cancer cell proliferation and survival. Nat Rev Cancer 8: 361-375. doi:10.1038/nrc2374

Saint Fleur-Lominy S, Maus M, Vaeth M, Lange I, Zee I, Suh D, Liu C, Wu X, Tikhonova A, Aifantis I, et al. 2018. STIM1 and STIM2 mediate cancer-induced inflammation in T cell acute lymphoblastic leukemia. Cell Rep 24: 3045-3060.e3045. doi:10.1016/j.celrep.2018.08.030

Schaar A, Sukumaran P, Sun Y, Dhasarathy A, Singh BB. 2016. TRPC1-STIM1 activation modulates transforming growth factor $\beta$-induced epithelial-to-mesenchymal transition. Oncotarget 7: 80554-80567. doi:10.18632/oncotar get.12895

Shapovalov G, Ritaine A, Skryma R, Prevarskaya N. 2016. Role of TRP ion channels in cancer and tumorigenesis Semin Immunopathol 38: 357-369. doi:10.1007/s00281015-0525-1

Singh A, Chagtoo M, Tiwari S, George N, Chakravarti B, Khan S, Lakshmi S, Godbole MM. 2017. Inhibition of inositol 1, 4, 5-trisphosphate receptor induce breast cancer cell death through deregulated autophagy and cellular bioenergetics. J Cell Biochem 118: 2333-2346. doi:10 $.1002 / \mathrm{jcb} .25891$

Sozucan Y, Kalender ME, Sari I, Suner A, Oztuzcu S, Arman K, Yumrutas O, Bozgeyik I, Cengiz B, Igci YZ, et al. 2015. TRP genes family expression in colorectal cancer. Exp 
S.J. Roberts-Thomson et al.

Oncol 37: 208-212. doi:10.31768/2312-8852.2015.37(3): 208-212

Stadler S, Nguyen CH, Schachner H, Milovanovic D, Holzner S, Brenner S, Eichsteininger J, Stadler M, Senfter D, Krenn L, et al. 2017. Colon cancer cell-derived 12(S)HETE induces the retraction of cancer-associated fibroblast via MLC2, RHO/ROCK and $\mathrm{Ca}^{2+}$ signalling. Cell Mol Life Sci 74: 1907-1921. doi:10.1007/s00018-0162441-5

Stewart TA, Yapa KT, Monteith GR. 2015. Altered calcium signaling in cancer cells. Biochim Biophys Acta 1848: 2502-2511. doi:10.1016/j.bbamem.2014.08.016

Sung PJ, Tsai FD, Vais H, Court H, Yang J, Fehrenbacher N, Foskett JK, Philips MR. 2013. Phosphorylated K-Ras limits cell survival by blocking Bcl-xL sensitization of inositol trisphosphate receptors. Proc Natl Acad Sci 110: 20593 20598. doi:10.1073/pnas.1306431110

Szatkowski C, Parys JB, Ouadid-Ahidouch H, Matifat F. 2010. Inositol 1,4,5-trisphosphate-induced $\mathrm{Ca}^{2+}$ signalling is involved in estradiol-induced breast cancer epithelial cell growth. Mol Cancer 9: 156. doi:10.1186/ 1476-4598-9-156

Takahashi N, Chen HY, Harris IS, Stover DG, Selfors LM, Bronson RT, Deraedt T, Cichowski K, Welm AL, Mori Y, et al. 2018. Cancer cells co-opt the neuronal redoxsensing channel TRPA1 to promote oxidative-stress tolerance. Cancer Cell 33: 985-1003 e1007. doi:10.1016/j .ccell.2018.05.001

Tedeschi A, Dupraz S, Laskowski CJ, Xue J, Ulas T, Beyer M, Schultze JL, Bradke F. 2016. The calcium channel subunit $\alpha 2 \delta 2$ suppresses axon regeneration in the adult CNS. Neuron 92: 419-434. doi:10.1016/j.neuron.2016.09.026

Tosatto A, Sommaggio R, Kummerow C, Bentham RB, Blacker TS, Berecz T, Duchen MR, Rosato A, Bogeski I, Szabadkai G, et al. 2016. The mitochondrial calcium uniporter regulates breast cancer progression via HIF-1 $\alpha$. $E M B O$ Mol Med 8: 569-585. doi:10.15252/emmm .201606255

Trebak M, Putney JW Jr. 2017. ORAI calcium channels. Physiology (Bethesda) 32: 332-342. doi:10.1152/physiol .00011 .2017

Tsavaler L, Shapero MH, Morkowski S, Laus R. 2001. Trp$\mathrm{p} 8$, a novel prostate-specific gene, is up-regulated in prostate cancer and other malignancies and shares high homology with transient receptor potential calcium channel proteins. Cancer Res 61: 3760-3769.

Umemura M, Baljinnyam E, Feske S, De Lorenzo MS, Xie LH, Feng X, Oda K, Makino A, Fujita T, Yokoyama U, et al. 2014. Store-operated $\mathrm{Ca}^{2+}$ entry (SOCE) regulates melanoma proliferation and cell migration. PLoS ONE 9: e89292. doi:10.1371/journal.pone.0089292

Vancauwenberghe E, Noyer L, Derouiche S, Lemonnier L, Gosset P, Sadofsky LR, Mariot P, Warnier M, Bokhobza A, Slomianny C, et al. 2017. Activation of mutated TRPA1 ion channel by resveratrol in human prostate cancer associated fibroblasts (CAF). Mol Carcinog 56: 1851-1867. doi:10.1002/mc.22642

VanHouten J, Sullivan C, Bazinet C, Ryoo T, Camp R, Rimm DL, Chung G, Wysolmerski J. 2010. PMCA2 regulates apoptosis during mammary gland involution and predicts outcome in breast cancer. Proc Natl Acad Sci 107: 11405-11410. doi:10.1073/pnas.0911186107
Warnier M, Roudbaraki M, Derouiche S, Delcourt P, Bokhobza A, Prevarskaya N, Mariot P. 2015. CACNA2D2 promotes tumorigenesis by stimulating cell proliferation and angiogenesis. Oncogene 34: 5383-5394. doi:10.1038/ onc.2014.467

Weaver VM, Fischer AH, Peterson OW, Bissell MJ. 1996. The importance of the microenvironment in breast cancer progression: Recapitulation of mammary tumorigenesis using a unique human mammary epithelial cell model and a three-dimensional culture assay. Biochem Cell Biol 74: 833-851. doi:10.1139/096-089

Weber LV, Al-Refae K, Wölk G, Bonatz G, Altmüller J, Becker C, Gisselmann G, Hatt H. 2016. Expression and functionality of TRPV1 in breast cancer cells. Breast Cancer (Dove Med Press) 8: 243-252. doi:10.2147/BCTT.S121610

Weidinger C, Shaw PJ, Feske S. 2013. STIM1 and STIM2mediated $\mathrm{Ca}^{2+}$ influx regulates antitumour immunity by $\mathrm{CD}^{+} \mathrm{T}$ cells. EMBO Mol Med 5: 1311-1321. doi:10.1002/ emmm.201302989

Wu Y, Xu X, Ma L, Yi Q, Sun W, Tang L. 2017. Calreticulin regulates TGF- $\beta 1$-induced epithelial mesenchymal transition through modulating Smad signaling and calcium signaling. Int J Biochem Cell Biol 90: 103-113. doi:10 $.1016 /$ j.biocel.2017.07.023

Xia J, Wang H, Huang H, Sun L, Dong S, Huang N, Shi M, Bin J, Liao Y, Liao W. 2016. Elevated Orail and STIM1 expressions upregulate MACC1 expression to promote tumor cell proliferation, metabolism, migration, and invasion in human gastric cancer. Cancer Lett 381: 31-40. doi:10.1016/j.canlet.2016.07.014

Xue H, Wang Y, MacCormack TJ, Lutes T, Rice C, Davey M, Dugourd D, Ilenchuk TT, Stewart JM. 2018. Inhibition of transient receptor potential Vanilloid 6 channel, elevated in human ovarian cancers, reduces tumour growth in a xenograft model. J Cancer 9: 3196-3207. doi:10.7150/jca .20639

Yang S, Zhang JJ, Huang XY. 2009. Orail and STIM1 are critical for breast tumor cell migration and metastasis. Cancer Cell 15: 124-134. doi:10.1016/j.ccr.2008.12.019

Yang N, Tang Y, Wang F, Zhang H, Xu D, Shen Y, Sun S, Yang G. 2013. Blockade of store-operated $\mathrm{Ca}^{2+}$ entry inhibits hepatocarcinoma cell migration and invasion by regulating focal adhesion turnover. Cancer Lett 330: 163-169. doi:10.1016/j.canlet.2012.11.040

Yang H, Liu C, Zhou RM, Yao J, Li XM, Shen Y, Cheng H, Yuan J, Yan B, Jiang Q. 2016. Piezo2 protein: A novel regulator of tumor angiogenesis and hyperpermeability. Oncotarget 7: 44630-44643. doi:10.18632/oncotarget .10134

Yang Y, Jiang Z, Ma N, Wang B, Liu J, Zhang L, Gu L. 2018. MicroRNA-223 targeting STIM1 inhibits the biological behavior of breast cancer. Cell Physiol Biochem 45: 856866. doi:10.1159/000487180

Yapa KT, Deuis J, Peters AA, Kenny PA, Roberts-Thomson SJ, Vetter I, Monteith GR. 2018. Assessment of the TRPM8 inhibitor AMTB in breast cancer cells and its identification as an inhibitor of voltage gated sodium channels. Life Sci 198: 128-135. doi:10.1016/j.lfs.2018 .02 .030

Ye X, Weinberg RA. 2015. Epithelial-mesenchymal plasticity: A central regulator of cancer progression. Trends Cell Biol 25: 675-686. doi:10.1016/j.tcb.2015.07.012 
Yue D, Wang Y, Xiao JY, Wang P, Ren CS. 2009. Expression of TRPC6 in benign and malignant human prostate tissues. Asian J Androl 11: 541-547. doi:10.1038/aja .2009 .53

Zhang L, Barritt GJ. 2004. Evidence that TRPM8 is an androgen-dependent $\mathrm{Ca}^{2+}$ channel required for the survival of prostate cancer cells. Cancer Res 64: 8365-8373. doi:10 1158/0008-5472.CAN-04-2146

Zhang Y, Weinberg RA. 2018. Epithelial-to-mesenchymal transition in cancer: Complexity and opportunities. Front Med 12: 361-373. doi:10.1007/s11684-018-0656-6

Zhang H, Zhou L, Shi W, Song N, Yu K, Gu Y. 2012. A mechanism underlying the effects of polyunsaturated fatty acids on breast cancer. Int J Mol Med 30: 487-494. doi:10.3892/ijmm.2012.1022

Zhang S, Miao Y, Zheng X, Gong Y, Zhang J, Zou F, Cai C. 2017. STIM1 and STIM2 differently regulate endogenous $\mathrm{Ca}^{2+}$ entry and promote TGF- $\beta$-induced EMT in breast cancer cells. Biochem Biophys Res Commun 488: 74-80. doi:10.1016/j.bbrc.2017.05.009

Zhivotovsky B, Orrenius S. 2011. Calcium and cell death mechanisms: A perspective from the cell death community. Cell Calcium 50: 211-221. doi:10.1016/j.ceca.2011 .03 .003

Zhong F, Harr MW, Bultynck G, Monaco G, Parys JB, De Smedt H, Rong YP, Molitoris JK, Lam M, Ryder C, et al.
2011. Induction of $\mathrm{Ca}^{2+}$-driven apoptosis in chronic lymphocytic leukemia cells by peptide-mediated disruption of Bcl-2-IP 3 receptor interaction. Blood 117: 2924-2934. doi:10.1182/blood-2010-09-307405

Zhou X, Friedmann KS, Lyrmann H, Zhou Y, Schoppmeyer R, Knörck A, Mang S, Hoxha C, Angenendt A, Backes CS, et al. 2018. A calcium optimum for cytotoxic T lymphocyte and natural killer cell cytotoxicity. J Physiol 596: 2681-2698. doi:10.1113/JP274964

Zhu Y, Pan Q, Meng H, Jiang Y, Mao A, Wang T, Hua D, Yao X, Jin J, Ma X. 2015. Enhancement of vascular endothelial growth factor release in long-term drug-treated breast cancer via transient receptor potential channel $5-\mathrm{Ca}^{2+}$ hypoxia-inducible factor $1 \alpha$ pathway. Pharmacol Res 93: 36-42. doi:10.1016/j.phrs.2014.12.006

Zhu S, Zhou HY, Deng SC, Deng SJ, He C, Li X, Chen JY, Jin Y, Hu ZL, Wang F, et al. 2017. ASIC1 and ASIC3 contribute to acidity-induced EMT of pancreatic cancer through activating $\mathrm{Ca}^{2+} / \mathrm{RhoA}$ pathway. Cell Death Dis 8: e2806. doi:10.1038/cddis.2017.189

Zhuang LY, Peng JB, Tou LQ, Takanaga H, Adam RM, Hediger MA, Freeman MR. 2002. Calcium-selective ion channel, CaT1, is apically localized in gastrointestinal tract epithelia and is aberrantly expressed in human malignancies. Lab Invest 82: 1755-1764. doi:10.1097/01 .LAB.0000043910.41414.E7 


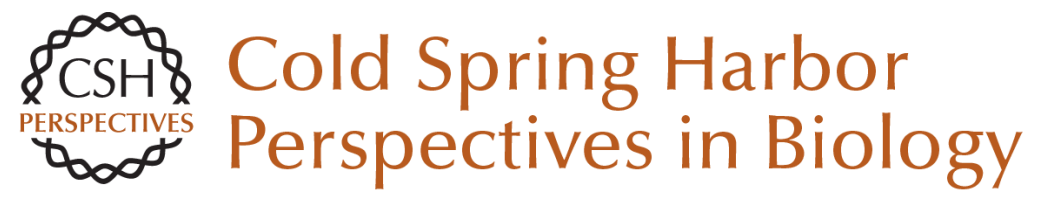

\section{The Calcium-Signaling Toolkit in Cancer: Remodeling and Targeting}

Sarah J. Roberts-Thomson, Silke B. Chalmers and Gregory R. Monteith

Cold Spring Harb Perspect Biol 2019; doi: 10.1101/cshperspect.a035204 originally published online May 14, 2019

\section{Subject Collection Calcium Signaling}

The Endoplasmic Reticulum-Plasma Membrane Junction: A Hub for Agonist Regulation of $\mathrm{Ca}^{2+}$ Entry

Hwei Ling Ong and Indu Suresh Ambudkar

Calcium-Handling Defects and Neurodegenerative Disease

Sean Schrank, Nikki Barrington and Grace E. Stutzmann

Lysosomal $\mathrm{Ca}^{2+}$ Homeostasis and Signaling in Health and Disease

Emyr Lloyd-Evans and Helen Waller-Evans

\section{$\mathrm{Ca}^{2+}$ Signaling in Exocrine Cells}

Malini Ahuja, Woo Young Chung, Wei-Yin Lin, et al.

Functional Consequences of Calcium-Dependent Synapse-to-Nucleus Communication: Focus on Transcription-Dependent Metabolic Plasticity Anna M. Hagenston, Hilmar Bading and Carlos Bas-Orth

Identifying New Substrates and Functions for an Old Enzyme: Calcineurin Jagoree Roy and Martha S. Cyert

Fundamentals of Cellular Calcium Signaling: A Primer

Martin D. Bootman and Geert Bultynck
Primary Active $\mathrm{Ca}^{2+}$ Transport Systems in Health and Disease Jialin Chen, Aljona Sitsel, Veronick Benoy, et al.

Signaling through $\mathrm{Ca}^{2+}$ Microdomains from Store-Operated CRAC Channels Pradeep Barak and Anant B. Parekh

Structural Insights into the Regulation of $\mathrm{Ca}^{2+}$ /Calmodulin-Dependent Protein Kinase II (CaMKII) Moitrayee Bhattacharyya, Deepti Karandur and John Kuriyan

Store-Operated Calcium Channels: From Function to Structure and Back Again Richard S. Lewis

Bcl-2-Protein Family as Modulators of $\mathrm{IP}_{3}$

Receptors and Other Organellar $\mathrm{Ca} 2+$ Channels Hristina Ivanova, Tim Vervliet, Giovanni Monaco, et al.

Calcium Signaling in Cardiomyocyte Function Guillaume Gilbert, Kateryna Demydenko, Eef Dries, et al.

Cytosolic $\mathrm{Ca}^{2+}$ Buffers Are Inherently $\mathrm{Ca}^{2+}$ Signal Modulators Beat Schwaller

For additional articles in this collection, see http://cshperspectives.cshlp.org/cgi/collection/

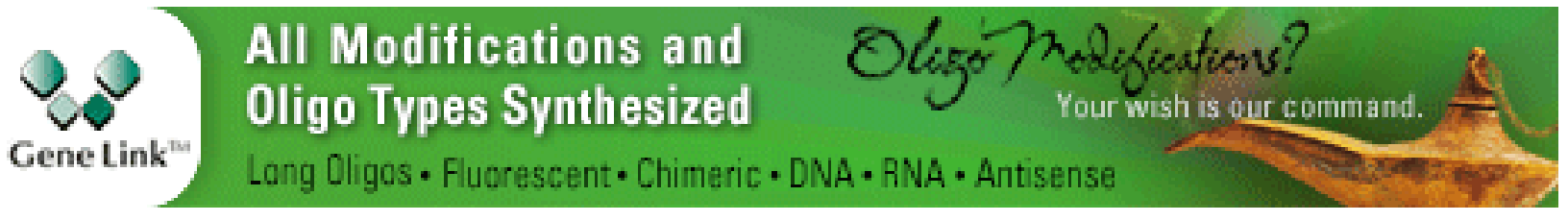


Role of Two-Pore Channels in Embryonic Development and Cellular Differentiation Sarah E. Webb, Jeffrey J. Kelu and Andrew L. Miller

\section{Organellar Calcium Handling in the Cellular \\ Reticular Network}

Wen-An Wang, Luis B. Agellon and Marek Michalak

For additional articles in this collection, see http://cshperspectives.cshlp.org/cgi/collection/

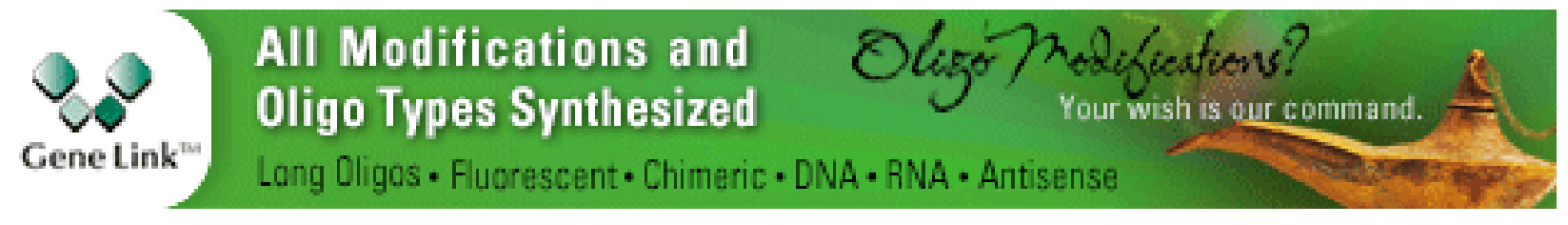

Copyright @ 2019 Cold Spring Harbor Laboratory Press; all rights reserved 